UNIVERSIDADE DE SÃO PAULO

INSTITUTO DE FÍSICA DE SÃO CARLOS

LUIS GUSTAVO SABINO

MODELO MATEMÁTICO DE DISTRIBUIÇÃO LARGA DE DOSE LIMIAR EM TUMORES SUBMETIDOS A MÚLTIPLAS SESSÕES DE TERAPIA FOTODINÂMICA

São Carlos - SP 



\section{MODELO MATEMÁTICO DE DISTRIBUIÇÃO LARGA DE DOSE LIMIAR EM TUMORES SUBMETIDOS A MÚLTIPLAS SESSÕES DE TERAPIA FOTODINÂMICA}

Dissertação apresentada ao Programa de PósGraduação em Física do Instituto de Física de São Carlos da Universidade de São Paulo para obtenção do título de Mestre em Ciências.

Área de concentração: Física Aplicada.

Opção: Biomolecular

Orientador: Profa. Dra. Cristina Kurachi

São Carlos - SP 
AUTORIZO A REPRODUÇÃO E DIVULGAÇÃO TOTAL OU PARCIAL DESTE TRABALHO, POR QUALQUER MEIO CONVENCIONAL OU ELETRÔNICO, PARA FINS DE ESTUDO E PESQUISA, DESDE QUE CITADA A FONTE.

Sabino, Luis Gustavo.

Modelo matemático de distribuição larga de dose limiar em tumores submetidos a múltiplas sessões de terapia fotodinâmica./.Luis Gustavo Sabino; orientadora Cristina Kurachi._ edição revisada - São Carlos, 2010.

$74 \mathrm{p}$.

Dissertação (Mestrado em Ciências - Área de concentração: Física Aplicada ) - Instituto de Física de São Carlos da Universidade de São Paulo.

1.Terapia fotodinâmica. 2. Modelo teórico. 3. Variabilidade celular . 4. Resposta tumoral. 5. Distribuição de dose limiar de luz. I. Título. 
Este exemplar foi revisado e alterado em relação à versão original sob a exclusiva responsabilidade do autor.

São Carlos, 25 de Fevereiro de 2010

\author{
Luis Gustavo Sabino
}



"A persistência é o caminho do êxito."

(Charles Chaplin) 



\section{AGRADECIMENTOS}

Ao bom Deus e aos meus pais, os responsáveis pela minha existência. Obrigado por iluminar meu caminho e me dar força na busca por meus sonhos e realizações.

A toda a minha família, a base da minha vida, o meu chão, obrigado pelo apoio. Agradeço também a minha namorada Nayara, pela compreensão e apoio na fase final deste trabalho.

Ao Professor Vanderlei S. Bagnato, exemplo de competência, perseverança e generosidade. Agradeço pelo suporte e a orientação durante o mestrado, e desejo que esteja presente nas próximas etapas da minha formação como pesquisador.

À Professora Cristina Kurachi que está sempre presente e pronta para ajudar e ensinar o que é necessário. Sendo muito importante para meu crescimento pessoal e profissional.

Ao Prof. Dr. José Eduardo Brunaldi do HCFMRP-USP.

Aos meus amigos do Laboratório de Biofotônica:

Mardo, Ruy, Clovão, Lili, Sebastião, Leandro, Natalia, Carla, Juçaira, Fernando, Éverton, Gustavão, Minatel, Jeison, Fernanda, Hilde, obrigado por todo o apoio e companheirismo. Especialmente ao Emery e José Dirceu pela ajuda durante a realização deste trabalho.

Aos amigos do Departamento de Cirurgia e Anatomia da FMRP-USP:

Prof. Dr. Luis Fernando Tirapelli, Prof. Dr. Daniela Pretti da Cunha Tirapelli e Ms. Paulo Cesar Novais. Obrigado pela ajuda nos experimentos.

A todos os amigos dos Laboratórios do Grupo de Óptica: pessoal do LAT, do LIEPO, da Atômica e da Difusão de ciências. Sempre prontos a me ajudar.

Aos amigos da secretaria: Isabel, Benê e Juliano.

A todos os professores do IFSC pelo conhecimento transmitido.

Ao CNPq pela bolsa de mestrado.

A todos do Instituto de Física de São Carlos. 



\section{RESUMO}

SABINO, L. G., Modelo matemático de distribuição larga de dose limiar em tumores submetidos a múltiplas sessões de terapia fotodinâmica. 2010. 74p. Dissertação (Mestrado - Física aplicada: Biomolecular) - Instituto de Física de São Carlos, Universidade de São Paulo, São Carlos, 2010.

A Terapia fotodinâmica (TFD) é uma conhecida opção terapêutica para diversos tipos de lesões malignas e não-malignas. A TFD age por meio de uma reação fotoquímica, formando agentes oxidativos que causam inúmeros danos às estruturas subcelulares e posterior morte da célula. Em grande parte dos casos são necessárias várias sessões da TFD para erradicação completa da lesão neoplásica. No entanto, vários estudos clínicos têm sido publicados mostrando recrescimento tumoral e um aumento na resistência do tumor às sessões posteriores da TFD. Neste estudo apresentamos um modelo teórico para descrever os efeitos causados por sucessivas sessões da TFD quando ocorre recrescimento tumoral. Para isso, considera-se uma distribuição de dose limiar que representa a variedade celular de um modelo teórico de tumor. A existência de uma variedade de células com diferentes doses limiares pode ser a causa de uma resposta parcial do tecido à terapia, implicando em recrescimento do tecido tumoral. Neste modelo, assume-se que esta distribuição de dose limiar é representada por uma distribuição Gaussiana modificada. Em termos de dose limiar, valores mais altos implicam em maior resistência à TFD. Se a distribuição é larga, o tratamento não é capaz de eliminar todas as células. A fração de células que sobrevivem promovem o recrescimento tumoral; no entanto, a população de células no tumor recrescido apresenta diferentes características quando comparada com a população de células do tumor original. Para avaliar a ocorrência da seleção das células mais resistentes foi realizada uma investigação sobre as alterações da resposta das células tumorais, após múltiplas sessões da terapia fotodinâmica. Para simular este tipo de procedimento foram realizadas sucessivas sessões da TFD em culturas de células de hepatocarcinoma (HepG2). Entre as sessões de TFD foi aguardado um intervalo de tempo suficiente para que as células sobreviventes se reproduzissem e formassem uma nova cultura celular. O fotossensibilizador utilizado nos experimentos foi o Photogem ${ }^{\circledR} \mathrm{e}$ a iluminação realizada em $630 \pm 10 \mathrm{~nm}$. Os resultados dos experimentos in vitro forneceram evidências do aumento da resistência das células neoplásicas da linhagem HepG2 após sucessivas aplicações da TFD. Este aumento é previsto pelo modelo teórico e pode estar relacionado com a variação das características da população celular, que é expressa neste modelo pela distribuição de dose limiar. No entanto, o aumento da resistência da população celular à TFD previsto pelo modelo teórico é mais acentuado do que o aumento observado no experimento com culturas celulares, portanto, mais estudos serão necessários para adequar o modelo à condição real. Com base na variabilidade das células tumorais, as simulações demonstraram que a dose de luz insuficiente pode induzir um aumento da resistência do tumor às posteriores sessões da TFD. Este modelo poderá ser utilizado para avaliar qual o tipo de distribuição de dose limiar pode-se encontrar em tumores reais e quais as consequiências causadas pela atenuação da luz em função da profundidade do tumor. A idéia apresentada neste estudo motivará novos estudos para identificar a importância da distribuição de dose limiar em tumores submetidos à TFD.

Palavras chave: Terapia fotodinâmica; modelo teórico; variabilidade celular; resposta tumoral; distribuição de dose limiar de luz. 



\begin{abstract}
SABINO, L. G., Mathematical model for broad distribution of threshold dose in tumors treated with multiple photodynamic therapy sessions. 2010. 74p. Dissertação (Mestrado Física aplicada: Biomolecular) - Instituto de Física de São Carlos, Universidade de São Paulo, São Carlos, 2010.

Photodynamic therapy is a well known treatment option for many types of malignant and nonmalignant lesions. This technique causes cell damage through a photochemical reaction, generating oxidative agents responsible for tumor cell killing. In several cases, multiple PDTsessions are needed to promote cancer eradication. However, several clinical studies have been reported an increase of tumor resistance after a PDT-session. We present a theoretical model to describe the effects caused by successive PDT sessions based on the consequences of a partial response caused by the threshold dose distribution within the hypothetical tumor. In this model, we assume that this threshold dose distribution is represented by a Modified Gaussian Distribution. In terms of threshold dose, higher values imply higher resistance to PDT. If the distribution is broad, the treatment cannot result in the killing of all tumor cells. The survival cell fraction promotes a tumor regrowth with different characteristics compared to the original cell population. We applied the model in a hypothetical tumor to exemplify the idea here presented. The qualitative analysis extracted from our theoretical model shows a behavior that is in agreement with results obtained in our results from in vitro experiments and several clinical observations. To investigate the occurrence of a selection of higher threshold dose cells, an experiment that evaluated the response of tumor cells after multiple sessions of photodynamic therapy was carried out. To simulate this procedure, successive sessions of PDT in hepatocellular carcinoma cells (HepG2) were performed. A time interval between PDT-sessions was respected to allow surviving cells division, resulting in a new cell culture. The photosensitizer used in the experiments was Photogem ${ }^{\circledR}$ and a $630 \pm 10 \mathrm{~nm}$ irradiation was performed. The result of in vitro experiments provided evidence of increasing resistance of HepG2 cells after successive PDT-sessions. This increase is predicted by the theoretical model and may be related to variations in the tumor cell population, which is expressed by the variation of the distribution of threshold dose, according to the model. However, the increased PDT resistance of the cell population provided by the theoretical model is more pronounced than the one experimentally observed. Based on tumor cell variability, the simulations demonstrated that insufficient light dose can induce an increase in tumor resistance to further PDT sessions. This model maybe used to evaluate which type of threshold dose distribution we can find in real tumors, and the consequences caused by light attenuation observed from the illuminated surface and deeper tumor regions. This proposed model shows relative agreement to clinical literature. However, further experimental observations shall improve the model here presented. The idea presented in this study shall motivate further studies to identify the importance of cell threshold distribution in tumors submitted to PDT techniques.
\end{abstract}

Keywords: Photodynamic therapy; theoretical model; cancer cells variability; tumor response; threshold dose distribution. 



\section{LISTA DE FIGURAS}

Figura 1 - Formação da massa tumoral. (a) Tumor pouco vascularizado em fase inicial de desenvolvimento. (b) Tumor com grande quantidade de vasos sanguíneos, em fase avançada de crescimento.

Figura 2 - Diagrama esquemático do efeito causado pela ação fotodinâmica em um tumor composto por uma população de células indiferenciadas que apresentam uma distribuição de dose limiar.

Figura 3 - (a) Decréscimo da dose de luz em função da profundidade para um tecido biológico utilizando-se o modelo de distribuição de luz baseado na Lei de Beer-Lambert. Os parâmetros utilizados são arbitrários. (b) Ilustração da entrega da dose de luz durante a sessão da TFD no modelo tumoral. Considera-se nesse modelo apenas a propagação da luz e os efeitos causados pela ação fotodinâmica em função da profundidade do tecido $z$.

Figura 4 - (a) Imagem de uma lâmina histológica de fígado de rato (100x) após a sessão da TFD com iluminação superficial, com células coradas em HE. Pode-se observar que à esquerda da profundidade de necrose as células estão mortas. (b) Representação gráfica da fração de morte para um tecido sadio, $\boldsymbol{z}_{\boldsymbol{t h}}$ representa a profundidade de necrose.

Figura 5 - Representação gráfica da curva de distribuição Gaussiana modificada de dose limiar $\left(\boldsymbol{g}\left(\boldsymbol{D}_{\boldsymbol{t h}}\right)\right.$. A largura da curva para o tumor original vale $\mathbf{1} \boldsymbol{\sigma}_{\mathbf{0}}$, de forma que o valor da dose limiar será apresentado em unidades de sigma $\left(\boldsymbol{\sigma}_{\mathbf{0}}\right)$ para simplificar a interpretação do modelo.

Figura 6 - Representação gráfica da simulação da fração de morte em função da profundidade (16) para diferentes valores de dose superficial $\left(D_{0}=1 \sigma_{\mathbf{0}}, 2 \sigma_{\mathbf{0}}, 3 \sigma_{0 .} . .10 \sigma_{0}\right)$.

Figura 7 - Largura da curva Gaussiana $\boldsymbol{\sigma}^{I}(\mathbf{z})$ em função da profundidade do tumor recidivo. As doses utilizadas na simulação foram $D_{0}=1 \sigma_{0}, 1.3 \sigma_{0}$ e $1.6 \sigma_{0}$.

Figura 8 - Representação gráfica da simulação da fração de morte em função da profundidade (3.23) para a segunda sessão da TFD com quatro das doses superficiais utilizadas na primeira sessão $\left(D_{0}=1 \sigma_{0}\right.$, $2 \sigma_{0}, 3 \sigma_{0}$ e $\left.4 \sigma_{0}\right)$

Figura 9 - (a) Ilustração da disposição dos frascos contendo as culturas celulares utilizada no experimento com TFD. (b) Representação gráfica da distribuição de luz em função da distância à superfície.

Figura 10 - Espectro de absorção do Photogem, revelando sua forte absorção de luz na região do ultravioleta (Banda de Soret, lado esquerdo do gráfico) e uma absorção mais fraca na região espectral do visível (Bandas Q, lado direito do gráfico)

Figura 11 - Equipamento Biotable utilizado para a iluminação das culturas celulares. Ele é composto por uma matriz de 24 diodos emissores de luz com alto brilho numa banda espectral centrada em $630 \mathrm{~nm}$, um corpo metálico para alinhamento óptico e confinamento da luz, um dissipador térmico para manter estável a temperatura dos diodos e uma fonte de energia que provê a tensão e a corrente de operação do equipamento.

Figura 12 - Dispositivo de medida da intensidade óptica emitida pela Biotable, o qual é composto por oito fotodetectores (BPW-34) acoplados a uma placa de cultura celular. 
Figura 13 - Imagem obtida durante a dosimetria da BioTable calibrando a terceira camada de células do experimento. Aqui apenas um dos fotodetectores ligados na placa de 24 poços está realizando a medida. Entre a superfície da BioTable e o fotodetector estão dois frascos (primeira e segunda camada de células) contendo meio de cultura DMEM.

Figura 14 -Resultado das aferições realizadas com os frascos empilhados. Os círculos representam o perfil de distribuição de luz em função da distância entre a superfície da BioTable e os frascos contendo meio de cultura. Os quadrados representam a intensidade para os frascos apenas.

Figura 15 -Dose de luz $\left(\mathrm{em} \mathrm{J} / \mathrm{cm}^{2}\right)$ entregue às culturas celulares empilhadas durante os experimentos com TFD in vitro, com relação à distância $(\mathrm{em} \mathrm{cm})$ da cultura celular à superfície da BioTable.

Figura 16 - Imagem ilustrativa da disposição dos frascos de cultura celular empilhados para simular várias camadas de um tecido em diferentes profundidades, recebendo iluminação durante a sessão da TFD.

Figura 17 - Fração de morte (\%) após sucessivas sessões da TFD em função da distância da cultura celular à superfície da BioTable. Utilizou-se a linhagem HepG2, cada cultura submetida a TFD foi cultivada novamente após a iluminação e contagem das células. A cultura celular originada das células sobreviventes a $1^{\circ}$ sessão da TFD foi submetida à $2^{\circ}$ sessão e assim sucessivamente, até a $5^{\circ}$ geração de células.

Figura 18 - Linha contínua: Fração de morte obtida da simulação da primeira sessão da TFD de acordo com o modelo, utilizando o valor da largura da Gaussiana de $48 \mathrm{~J} / \mathrm{cm} 2$. Círculos: Curva de fração de morte celular obtida após a primeira sessão da TFD nos experimentos in vitro. Linha tracejada: Curva de fração de morte celular obtida da simulação da primeira sessão da TFD de acordo com o modelo teórico, utilizando um valor da largura da Gaussiana ajustado. 


\section{Sumário}

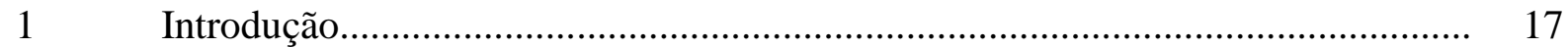

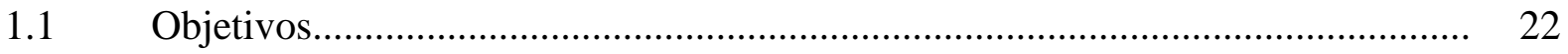

2 Câncer e a Terapia fotodinâmica..................................................................... 23

2.1. Câncer e a formação tumoral........................................................................ 23

2.2. Terapia fotodinâmica........................................................................ 25

2.1.1. Princípio da ação fotodinâmica........................................................................... 25

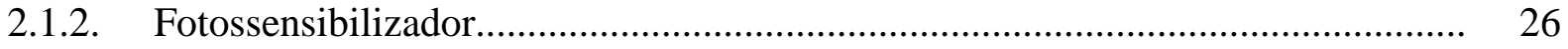

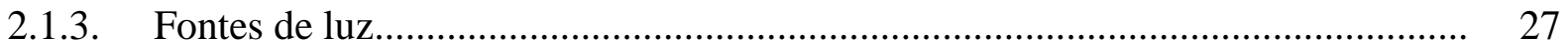

2.1.4. Alternativas para erradicação tumoral.................................................................. 28

3 Modelo matemático para distribuição de $D_{t h}$ : Efeito em múltiplas sessões da TFD

3.1 Modelo de Dose limiar para um tecido normal uniforme.................................. 30

3.2 Um modelo com variabilidade de dose limiar para a Terapia Fotodinâmica........ 35

3.3 Fração de morte após a primeira sessão da TFD................................................ 39

3.4 Recrescimento do tumor após a $1^{\circ}$ sessão da TFD e fração de morte após a $2^{\circ}$ sessão.

4. Evidências experimentais das alterações da resposta à TFD após múltiplas sessões.

4.1 Descrição do experimento............................................................................ 48

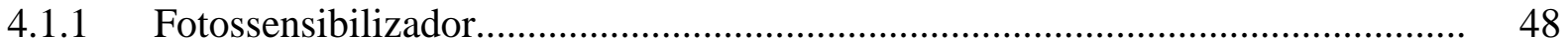

4.1.2 Linhagem celular....................................................................................... 50

4.1.3 Cultivo celular...................................................................................... 50

4.1.4 Contagem das células........................................................................... 51

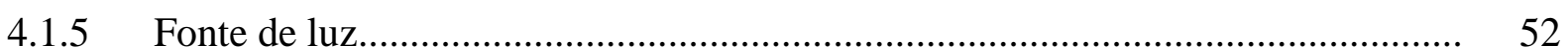

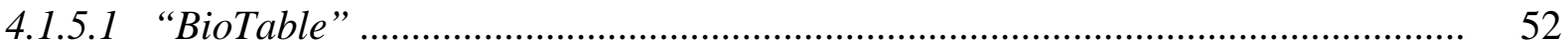

4.1.5.2 Caracterização da BioTable ................................................................................ 54

4.2 Resultados experimentais............................................................................ 58

4.2.1 Terapia fotodinâmica in vitro.......................................................................... 58

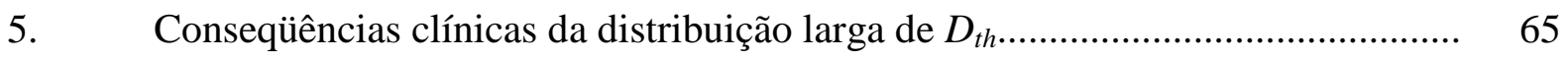

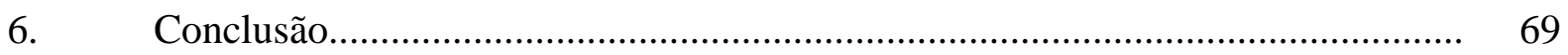

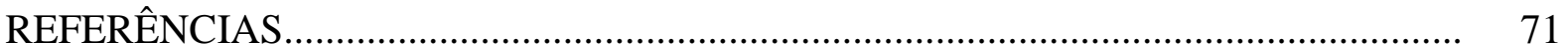





\section{Introduçãa}

A terapia fotodinâmica (TFD) é uma promissora modalidade terapêutica que tem sido utilizada no tratamento de diversos tipos de lesões malignas e não-malignas. A TFD age por meio de uma reação fotoquímica, formando agentes oxidativos que causam inúmeros danos às estruturas subcelulares e posterior morte da célula. Durante a TFD, um agente fotossensibilizador (FS) é administrado no paciente e após um período determinado de tempo se concentra seletivamente no tumor. Em seguida, o tumor recebe uma quantidade de luz de comprimento de onda específico com a intenção de ativar o fármaco. Ao absorver a energia dos fótons, o fotossensibilizador é promovido a um estado de mais alta energia, porém instável; buscando a estabilidade, o FS transfere energia para o oxigênio molecular presente nas células, resultando na formação de diferentes espécies reativas de oxigênio (EROs). Estas espécies reativas são moléculas de alto potencial oxidativo, principais responsáveis pela morte celular $^{1,2}$.

A terapia fotodinâmica age na eliminação de tecidos neoplásicos por meio de um princípio simples, com alta seletividade. Uma das vantagens da TFD é o efeito colateral controlado, que ocorre apesar da seletividade do fotossensibilizador por tecidos tumorais; a aplicação da TFD provoca a sensibilidade dérmica e ocular à luz. Este efeito depende do tipo de FS utilizado, podendo durar de algumas horas a quatro semanas. Dessa maneira, a TFD pode ser repetida várias vezes. Além disso, pode-se utilizá-la em conjunto com outras técnicas, como a radioterapia e a cirurgia ${ }^{3,4}$.

No caso dos derivados de hematoporfirina, o FS é injetado na corrente sanguínea e se distribui pelo corpo do paciente, sendo absorvido por todas as células; no entanto, as células sadias eliminam o FS em um intervalo de tempo inferior ao intervalo de tempo necessário para as células neoplásicas, que apresentam um metabolismo alterado e retêm o FS por um tempo mais prolongado. Desta forma, após determinado tempo da administração, o FS estará mais concentrado nas células neoplásicas, garantindo seletividade tumoral à ação fotodinâmica. Neste momento, a luz é entregue ao tecido tumoral, desencadeando a ação fotodinâmica através da excitação da molécula do fotossensibilizador, levando-a ao estado tripleto. O FS tripleto interage com as biomoléculas celulares causando oxidações, gerando 
fotoprodutos citóxicos (EROs) que causam danos às estruturas macromoleculares e perda da função; o principal fotoproduto citotóxico para porfirinas é o oxigênio singleto (reação tipo II, na seqüência), formado por cruzamento intersistema que ocorre no oxigênio molecular após a interação com o FS tripleto ${ }^{4}$. A consequiência desses danos é a morte das células, a eliminação do tecido neoplásico e a reconstituição do tecido sadio. Acredita-se que existam dois tipos dominantes de reação de formação de EROs durante a ação da TFD:

Reação tipo I ou via formação de radicais: o FS no estado excitado interage com as biomoléculas, abstraindo um átomo de hidrogênio (1.1) de uma molécula do substrato biológico (fosfolipídios, colesterol, proteínas, etc.) ${ }^{5}$ ou transferindo elétrons (1.2). Gerando íons radicais que tendem a reagir com o oxigênio no estado fundamental produzindo agentes oxidados responsáveis pela cadeia de radicais livres gerados, que provocam lesões celulares e a morte celular. Nas Equações 1.1 e 1.2 representa-se o FS no estado tripleto como ${ }^{3} \mathrm{~S}^{*}$, o substrato biológico como SB e o FS no estado fundamental como S:

$$
\begin{aligned}
& { }^{3} \mathrm{~S}^{*}+\mathrm{SB} \rightarrow \mathrm{S}+\mathrm{SB}^{-} \\
& { }^{3} \mathrm{~S}^{*}+\mathrm{SBH}_{2} \rightarrow \mathrm{HS}+\mathrm{SBH}
\end{aligned}
$$

Reação tipo II ou via formação de oxigênio singleto: $O$ fotossensibilzador no estado tripleto transfere energia ao oxigênio molecular no estado fundamental (tripleto) produzindo o oxigênio singleto; molécula altamente citotóxica responsável por danos celulares e a morte celular. O FS retorna ao estado fundamental, embora possa ser degradado pelo próprio oxigênio singleto ${ }^{4,6}$. A equação (1.3) abaixo representa o FS no estado tripleto como ${ }^{3} \mathrm{~S}^{*}$, o oxigênio molecular como ${ }^{3} \mathrm{O}_{2}$, o FS no estado fundamental como $\mathrm{S}$ e o oxigênio singleto como ${ }^{1} \mathrm{O}_{2}$ :

$$
{ }^{3} \mathrm{~S}^{*}+{ }^{3} \mathrm{O}_{2} \rightarrow \mathrm{S}+{ }^{1} \mathrm{O}_{2}
$$


Os dois mecanismos promovem a formação de EROs simultaneamente durante a iluminação da lesão, com a predominância de um deles dependendo do FS utilizado. O acúmulo de danos celulares induz a célula à morte por apoptose ou por necrose. Desta forma, a aplicação clínica terapêutica em TFD é resultado de uma intervenção específica e controlada, tanto do fotossensibilizador, que desencadeia os processos oxidativos, quanto da luz, utilizada para sua excitação, ${ }^{4,6}$.

Considerando o microsistema celular, existe um dano oxidativo mínimo que deve ser provocado para que a célula entre em processo de necrose ou apoptose. Nesse sentido, a reação fotodinâmica deve ocorrer com uma taxa mínima de maneira que os danos celulares induzidos sejam irreversíveis. O FS, após transferir a energia para o oxigênio tripleto, pode ser novamente excitado, podendo resultar na produção de novas EROs. Esse fenômeno pode ocorrer até que a molécula do FS seja degradada ${ }^{4}$. Existe uma vasta literatura sobre estudos de dosimetria da TFD, envolvendo estudo das propriedades ópticas dos tecidos, eficiência da terapia, entendimento de mecanismos de ação e estratégias de tratamento ${ }^{7-9}$. Em estudos realizados com modelo animal, a TFD foi aplicada em fígado de ratos para posterior avaliação da ação fotodinâmica a nível tecidual e celular. Entre 24 e 30 horas da aplicação da TFD, observou-se, através de imagens microscópicas das lâminas histológicas do tecido, uma fronteira bem definida entre a região de tecido necrosado e a região não-necrosada. Esta observação associada a um modelo de distribuição de luz no tecido mostra que a morte celular num tecido sadio depende exclusivamente da quantidade de dano celular causado pela formação local de fotoprodutos citotóxicos. Quando esta quantidade exceder um valor mínimo, a necrose acontece ${ }^{7}$.

A luz pode ser entregue ao tecido por iluminação superficial ou intersticial utilizando fibras ópticas com pontas especiais, o tipo de iluminação depende do volume do tumor e da sua localização. A iluminação superficial é mais utilizada em lesões de menor extensão, no entanto, a luz penetra muito pouco no tecido biológico. Isso se deve ao decréscimo exponencial que a luz sofre no tecido. Desta forma, a necrose causada pela TFD na lesão neoplásica é praticamente superficial ${ }^{1,10}$.

Assumindo que as células tumorais contenham as quantidades de FS e de oxigênio molecular necessárias para a formação dos agentes citotóxicos, a morte celular dependerá exclusivamente da quantidade de fótons que chegam ás moléculas de FS, ou seja, os fótons que estão em "trânsito" no microambiente celular. Desta forma, a morte celular ocorrerá nas 
regiões em que a dose de luz entregue supera a dose mínima de luz necessária para que ocorra a necrose, chamada de dose limiar $\left(D_{t h} \text {, do inglês threshold dose }\right)^{7,11}$. Nesse caso, o esperado é que o volume de necrose fosse homogêneo. A partir dessa observação, pode-se definir a $D_{t h}$ como um parâmetro relacionado à resistência das células à morte através da TFD, que depende do tipo e da localização da célula no tecido, bem como do tipo de tecido que se deseja eliminar.

Num estudo clínico, Corti e colaboradores ${ }^{12}$ realizaram o tratamento de 62 pacientes com câncer de esôfago em estágios iniciais, nos quais a intervenção cirúrgica era inviável. O tratamento apenas com a TFD, resultou numa taxa de erradicação de 37\% (23 de 62 casos). Neste mesmo trabalho, nos casos em que duas sessões da TFD não causaram a eliminação do tecido neoplásico, a radioterapia foi aplicada, alcançando 82\% (51 de 62 casos) de erradicação tumoral. Estes resultados mostram que a TFD é eficaz no tratamento curativo de lesões neoplásicas em fase inicial. Nestes casos, a lesão tem dimensões menores e nota-se que a TFD age com mais eficácia, pois a distribuição de luz no tecido é mais efetiva, alcançando o $D_{t h}$ em toda a lesão cancerosa.

No entanto, nos casos de câncer de esôfago em estágios avançados, a TFD tem sido usada como tratamento paliativo, visando à redução do volume tumoral ou o controle do seu crescimento, na tentativa de aumentar a sobrevida do paciente. Neste sentido, inúmeros estudos clínicos têm sido realizados, para avaliar a eficácia da técnica e possíveis complicações que podem ocorrer após sucessivas sessões da TFD. Em seu estudo clínico, Maier e colaboradores relatam uma melhora na qualidade de vida de pacientes com tumor de esôfago em estágio avançado, porém a erradicação do tumor não é obtida na maioria dos casos. Tumores em estágios avançados apresentam grandes extensões e espessura que varia de alguns milímetros a centímetros, de forma que a penetração da luz no tecido se torna um limitante para a técnica da TFD, pois a dose limiar não pode ser entregue a todas as regiões do tecido tumoral. Isto acaba levando ao recrescimento tumoral ${ }^{13}$ e à repetição das sessões de TFD. Não se sabe ao certo, porém, se a TFD pode induzir alterações no tumor e quais estas alterações $^{13,14}$.

Muitos estudos têm proposto protocolos para adicionar a resposta tumoral às considerações quanto ao planejamento da TFD. Entretanto, alguns estudos têm reportado casos de recorrência tumoral após o tratamento ${ }^{3,13,15,16}$. Nesses casos, é possível inferir que 
aplicações subseqüentes da TFD serão cada vez menos eficientes, resultando em um tumor recrescido cada vez mais resistente, com um alto valor de $D_{t h}$.

Quando a recorrência tumoral ocorre, supõe-se que as células sobreviventes, que foram a causa da recorrência, são mais resistentes à TFD, de alguma forma ainda não compreendida. Desta forma, o aumento da resistência tumoral pode estar relacionado com o tipo celular presente no tumor, ou ocorrer devido a variações na $D_{t h}$ do tecido tumoral após a TFD. Além disso, a grande heterogeneidade celular dentro de um tumor em fase avançada pode ser um fator determinante na resposta tumoral à TFD.

Ao contrário de tecidos normais (onde as células são diferenciadas, ou seja, são semelhantes às células pertencentes ao tecido normal, e apresentam alto grau de homogeneidade), os tumores são constituídos por uma população celular heterogênea, formada por uma distribuição larga de variedade celular. Isto pode gerar uma diferença na resposta celular à TFD e conseqüientemente, variações na resposta tumoral dependendo do estágio de desenvolvimento do tecido neoplásico ${ }^{17}$.

Em nossa concepção, neste caso, é possível que a TFD cause uma seleção das células mais resistentes, que apresentem $D_{t h}$ mais altas. Sendo assim, as características deste tipo de tumor podem se alterar após sucessivas aplicações da TFD. Em 2003, Shimada e colaboradores $^{14}$, publicaram um estudo com culturas celulares, observou-se a sobrevivência de 31 culturas de células de tumor de esôfago após a TFD. Neste estudo, eles observaram que várias colônias de morfologia diferente são formadas em cada cultura celular, criando uma variedade muito grande de células, mesmo sendo as células originadas de um mesmo tipo de celular. A literatura científica relata que em tecido as células se comportam de maneira diferente; sendo assim, é possível imaginar que esta variedade celular seja acentuada em uma lesão neoplásica ou tumor.

Adicionalmente, tem sido observado em culturas celulares que o aparecimento de resistência celular à morte através da quimioterapia pode estar associado às mudanças nos componentes do citoesqueleto. A quimioterapia tem como princípio a administração de drogas que eliminam seletivamente células neoplásicas. Estudos anteriores mostraram que a ação fotodinâmica afeta consideravelmente a adesão célula-célula e a adesão célula-substrato, o que, conseqüentemente, causam modificações no citoesqueleto ${ }^{18}$. Estas modificações da estrutura celular podem causar alterações na distribuição do FS e do oxigênio molecular, alterando a $D_{t h}$ destas células.

O objetivo deste estudo, portanto, é descrever uma idéia, apresentada como um modelo teórico, para avaliar a resposta de um modelo de tumor após sucessivas aplicações de 
TFD, no qual uma distribuição não muito estreita de valores de $D_{t h}$ é atribuída à população celular do modelo tumoral, representando sua resistência à TFD. A conseqüência desta distribuição é que, para uma dada dose de luz entregue a certa região do tecido, apenas uma fração das células será morta (as de $D_{t h}$ mais baixo). As sobreviventes determinam as características do tumor recrescido com consequiências para a repetição da TFD que podem prejudicar o tratamento. Esta hipótese é um caminho para o entendimento das possíveis limitações da TFD e de novas intervenções para a melhoria do processo fotodinâmico no caso de múltiplas aplicações, contribuindo para o aumento da eficácia da TFD no tratamento de tumores e no aumento da sobrevida dos pacientes. Nosso trabalho expõe um modelo teórico para o processo de resposta tumoral, e realiza um primeiro experimento demonstrando as possíveis conexões com a realidade.

\subsection{Objetivos}

O objetivo desse trabalho é o desenvolvimento de um modelo teórico para a representação da resposta tumoral a sucessivas sessões da TFD. Por meio deste, pretende-se avaliar a possibilidade da existência da distribuição larga de dose limiar em um tumor e suas possíveis conseqüências na TFD clínica. 


\section{Câncer e a Terapia fotodinâmica}

\subsection{Câncer e a formação tumoral}

No organismo humano, as células se reproduzem pela duplicação de seu conteúdo, dividindo-se em duas num processo chamado ciclo celular; este processo é rigidamente controlado. O ciclo celular é iniciado por sinais apropriados e dividido em várias etapas. $\mathrm{Na}$ ausência desses sinais a célula permanece no estado de repouso. No entanto, as células que sofreram mutações e não respondem ao controle da divisão celular, dividem-se independentemente das necessidades reais do organismo, formando as neoplasias e os tumores. Se as células neoplásicas permanecerem como um tumor intacto, o tumor é benigno e pode ser removido cirurgicamente. Entretanto, se novas mutações tornarem as células capazes de invadir e colonizar outros tecidos, formando tumores ou metástases secundários disseminados, o tumor é considerado maligno e é classificado como câncer. Cada tipo de câncer se origina de uma única célula que sofreu uma mutação transmissível e que permite o crescimento excessivo em relação às demais células do tecido, a formação da massa tumoral pode ser visualizada na Figura 1. Evidentemente, uma única mutação não é suficiente para transformar uma célula sadia em cancerosa; várias mutações raras têm que ocorrer simultaneamente ${ }^{4,19,20}$. 
(a)

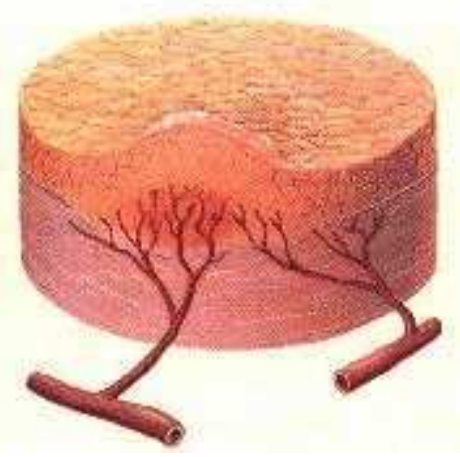

(b)

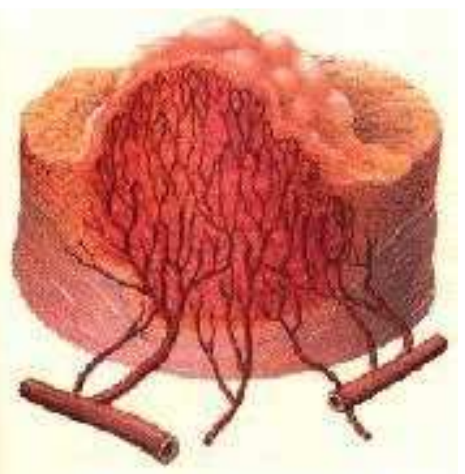

Figura 1 - Formação da massa tumoral. (a) Tumor pouco vascularizado em fase inicial de desenvolvimento. (b) Tumor com grande quantidade de vasos sanguíneos, em fase avançada de crescimento ${ }^{21}$.

Existem mais de 100 tipos de câncer, que correspondem aos vários tipos de células que compõem os diferentes tecidos do corpo humano. Por exemplo, existem diversos tipos de câncer de pele porque a pele contém diversos tipos de célula. Algumas das características que diferencia os diversos tipos de câncer entre si são a velocidade de multiplicação das células, e a capacidade de invadir tecidos e órgãos vizinhos ou distantes (metástases). Desde 2003 no Brasil, as neoplasias malignas constituem-se na segunda causa de morte na população, representando quase 17\% dos óbitos de causa conhecida, notificados em 2007 no Sistema de Informações sobre Mortalidade ${ }^{19}$.

Em 2010, são esperados 236.240 casos novos para o sexo masculino e 253.030 para o sexo feminino. Estima-se que o câncer de pele do tipo não melanoma (114 mil casos novos) será o mais incidente na população brasileira, seguido pelos tumores de próstata (52 mil), mama feminina (49 mil), cólon e reto (28 mil), pulmão (28 mil), estômago (21 mil) e colo do útero (18 mil). Nesse cenário, torna-se fundamental que os recursos e esforços sejam direcionados no sentido de orientar as estratégias de prevenção e controle de câncer. $\mathrm{O}$ estabelecimento de medidas efetivas para o controle do câncer pressupõe melhor compreensão sobre a doença e seus determinantes, avaliação dos avanços tecnológicos aplicados à prevenção e tratamento, bem como a efetividade da atenção à saúde ${ }^{19}$.

Diante desse aumento do número de casos de câncer surge a necessidade do estudo e da utilização de técnicas alternativas para o tratamento do câncer, que corroborem com a diminuição do número de pacientes com câncer. Principalmente aqueles casos em fase inicial, em que o paciente espera por tratamento com técnicas convencionais. Porém, as técnicas de combate ao câncer devem ser eficazes e seguras. Neste contexto, a Terapia fotodinâmica 
(TFD) tem se mostrado promissora no tratamento de vários tipos de câncer. Desde a década de 80, a TFD tem sido utilizada no tratamento de inúmeros casos de câncer de pele, cabeça e pescoço, tumores cerebrais, entre outros tipos; apresentando resultados satisfatórios. No Brasil, desde o final da década de 90, a TFD tem sido estudada e usada no tratamento de diversos tipos de câncer, apresentando resultados favoráveis ${ }^{22}$.

\subsection{Terapia fotodinâmica}

\subsubsection{Princípio da ação fotodinâmica}

No protocolo de tratamento sistêmico, um agente fotossensibilizador (FS) é administrado ao paciente e se distribui por todo o corpo, concentrando-se nas células da lesão neoplásica ou tumor. Após um intervalo de tempo (específico para cada tipo de FS), o FS se concentra no tumor, que em seguida recebe uma dose de luz de comprimento de onda específico. A absorção da luz causa uma mudança de estado da molécula de FS formando o fotossensibilizador no estado tripleto (FS*). Para que o FS* deixe este estado metaestável ele poderá liberar o excesso de energia emitindo fluorescência ou irá interagir com as biomoléculas do meio intracelular e membranas celulares ou outras moléculas presentes no microambiente. Dentre os milhares de moléculas, a mais importante para a ação citotóxica da TFD é o oxigênio molecular $\left(\mathrm{O}_{2}\right)$; após a interação entre o FS* e o $\mathrm{O}_{2}$ forma-se o oxigênio singleto, uma molécula de altíssimo potencial oxidativo e a principal responsável pelo dano e posterior morte celular ${ }^{1,11}$.

A destruição das células tumorais pode ocorrer por necrose ou apoptose. No processo de necrose, o acúmulo de danos em estruturas supramoleculares, organelas e, principalmente, a lise das membranas inviabilizam as reações bioquímicas indispensáveis para o funcionamento da célula, causando a morte celular. Além disso, outra via de morte celular pode ser desencadeada num processo chamado de apoptose. No processo de apoptose a morte celular é 
provocada por agentes apoptóticos, que através de uma cadeia complexa de reações bioquímicas destroem a célula. Apesar de agirem de forma diferente, os processos de necrose e apoptose ocorrem simultaneamente induzidos pela ação fotodinâmica. Por fim, outro efeito que pode desencadear a morte celular é o dano térmico causado pela utilização de intensidade alta de luz na região da lesão durante a TFD ${ }^{23}$.

\subsubsection{Fotossensibilizador}

O fotossensibilizador (FS) ideal deve apresentar propriedades específicas que garantam a eficácia e a segurança do tratamento. Por isso devem apresentar baixa citotoxicidade no escuro e propriedades fotofísicas adequadas. Ao absorver a luz, um elétron da molécula de FS é excitado do estado fundamental para o estado singleto (spins emparelhados). O retorno para o estado fundamental pode ocorrer através da emissão de fluorescência, ou pela transição para o estado tripleto (spins paralelos), de menor energia, por cruzamento intersistema, o qual requer uma inversão de spins. Pelas regras espectroscópicas este processo não é permitido, apesar disso, ocorre e representa uma das principais características de um bom FS, a alta eficiência em sofrer cruzamento intersistema ${ }^{4}$.

De forma geral, as propriedades esperadas de um bom agente fotossensibilizador são:

i. Solubilidade e estabilidade em solução aquosa a $\mathrm{pH}$ fisiológico que permitam sua distribuição e acúmulo nas células;

ii. Seletividade por células neoplásicas;

iii. Possuir estrutura que possibilite seu transporte passivo ou ativo para dentro das células e concentrar-se próximo a um alvo intracelular;

iv. Apresentar alto rendimento quântico (alta absorção de fótons);

v. Não ser tóxico a níveis terapêuticos, e cause danos colaterais mínimos ao paciente ${ }^{24}$.

Existem diversos tipos de FS classificados em FS de primeira, segunda e terceira geração. Os FS de primeira geração são compostos de derivados de hematoporfirina, como o Photofrin $^{\circledR}$, Photogem ${ }^{\circledR}$ e Photosan ${ }^{\circledR}$. As porfirinas representam os FS mais utilizados em 
estudos e aplicações clínicas, e são os únicos aprovados para uso em pacientes com câncer por órgãos reguladores de medicamentos e equipamentos médicos e odontológicos, como a FDA (Food and Drug Administration) e a ANVISA (Agência Nacional de Vigilância Sanitária). Alguns FS de segunda e terceira gerações, como as Clorinas e Ftalocianinas, apresentam a vantagem de absorverem com eficácia luz de comprimentos de onda maiores (acima de 650 $\mathrm{nm}$ ), além de causarem menores tempos de fotossensibilidade dérmica. Se a utilização destes FS for possível a TFD poderia agir de forma ainda mais eficaz a nível tecidual, aumentando a profundidade de morte celular induzida. Entretanto, os estudos clínicos com estes FS ainda estão sendo realizados para a definição dos melhores protocolos clínicos ${ }^{4}$.

\subsubsection{Fontes de luz}

As fontes de luz utilizadas em TFD devem permitir acoplamento com fibras ópticas de forma prática e eficiente, produzir feixes de alta intensidade (1-10 Watts) no comprimento de onda específico ao FS utilizado, apresentar preço acessível e segurança no funcionamento. Inicialmente as lâmpadas foram utilizadas na TFD para o tratamento de lesões de pele e estudos laboratoriais. Seu baixo custo, a simplicidade e a segurança na operação são algumas das vantagens das lâmpadas; entretanto, a necessidade de filtros para selecionar o comprimento de onda e a baixa intensidade de luz produzida reduz as possibilidades de utilização. Outra opção é o LED (acrônimo de light-emitting diode) que produz feixes de luz de uma banda relativamente estreita de emissão com intensidade aceitável para aplicações em TFD, porém não permitem acoplamento com fibras ópticas ${ }^{1}$.

A fonte de luz que ainda é a mais indicada para a maioria das aplicações é o sistema laser (SL), pois produz feixes monocromáticos (monocromaticidade - característica de uma fonte que emite fótons de comprimento de onda específico, em uma banda estreita) de alta energia. Existem vários SL que atendem às necessidades da TFD, entre eles o Nd:YAG que pode gerar feixes com comprimento de onda de 200 à 2000 nm utilizando-se alguns dispositivos ópticos, alcançando assim o pico de absorção de todos os FSs comercializados, no entanto, o seu elevado custo é uma desvantagem ${ }^{25}$. Em aplicações clínicas, o SL mais 
empregado é o laser de diodo, com diversas opções de emissão no espectro do visível e do infravermelho. O SL de diodo é compacto, portátil e de fácil operação, por isso tem sido utilizado com mais frequiência em estudos laboratoriais e como ferramenta clinica ${ }^{2525}$. O SL de diodo permite acoplamento com as fibras ópticas, o que permite transmissão da luz e a utilização da TFD no tratamento de lesões localizadas no esôfago, traquéias, estômago, intestinos, entre outras possibilidades de iluminação.

\subsubsection{Alternativas para erradicação tumoral}

Existem dois principais caminhos para a destruição tumoral via TFD, são eles:

- Destruição Indireta: caminho iniciado pela destruição do sistema vascular (endotélio e outros componentes da parede vascular) e/ou da matriz intercelular, seguido pela hipóxia tecidual, que resulta na morte de células neoplásicas;

- Destruição Direta: células tumorais morrem como conseqüência do mau funcionamento de, por exemplo, funções mitocondriais e de sistemas de membranas celulares $^{26}$. 


\section{Modelo matemático para distribuição de $D_{t h}$ : Efeito em múltiplas sessões da TFD}

Neste capítulo será analisado o efeito da existência de uma distribuição de dose limiar $\left(D_{t h}\right)$, ao invés de um único valor num modelo de tecido uniforme. Primeiro, analisaremos a resposta à ação fotodinâmica de um tumor formado por uma população de células de alto grau de diferenciação (células neoplásicas semelhantes às células normais), e suas implicações para sucessivas sessões da TFD. Em seguida, considera-se um tecido neoplásico que é formado por uma variedade de tipos celulares que se pode representar por uma distribuição de probabilidade. A distribuição de $D_{t h}$ e seu comportamento durante a ação fotodinâmica serão avaliados considerando-se um modelo tumoral composto por uma população celular que apresenta variabilidade de $D_{t h}$ e é uniformemente distribuída ao longo do volume tumoral. A variabilidade da $D_{t h}$ no tumor é representada por uma distribuição Gaussiana modificada de dose limiar. Para exemplificar o conceito de distribuição de $D_{t h}$, foram realizadas simulações para investigar os efeitos causados por duas sessões da TFD em seqüência no modelo de tumor original, supondo que após a primeira sessão ocorra o recrescimento tumoral. Este processo está sintetizado no esquema da Figura 2, para mais fácil visualização. Entendendo os fatores dominantes de duas sessões seguidas é possível generalizar para seqüências maiores.

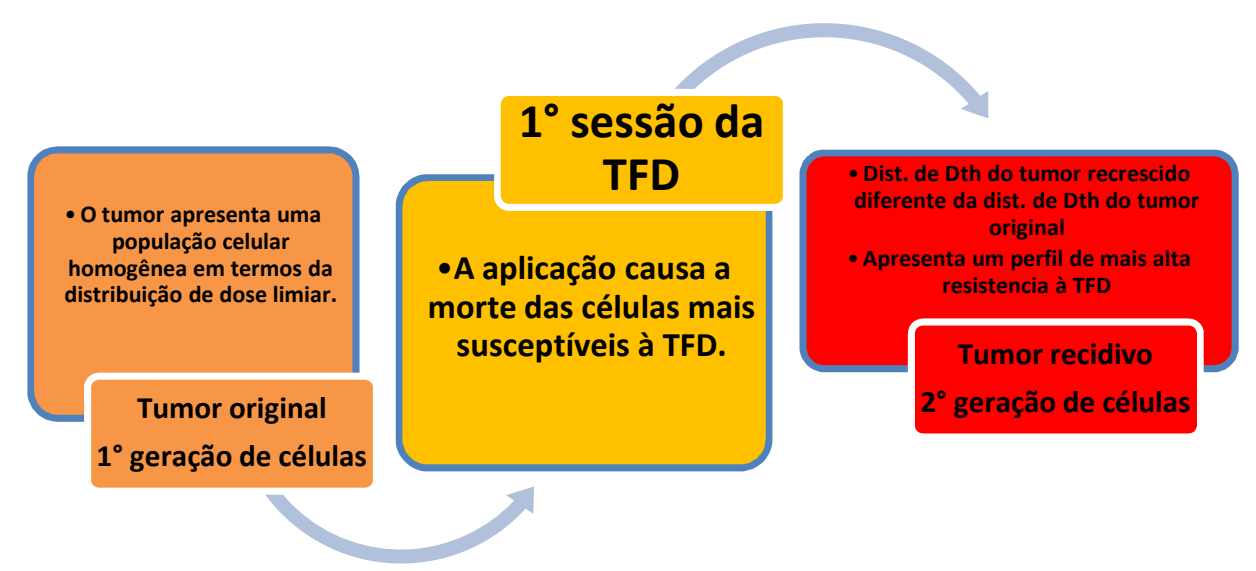

Figura 2 - Diagrama esquemático do efeito causado pela ação fotodinâmica em um tumor composto por uma população de células de baixo grau de diferenciação que apresentam uma distribuição de dose limiar. 


\subsection{Modelo de Dose limiar para um tecido normal uniforme}

Durante a ação fotodinâmica, a morte celular ocorre desde que a quantidade de fotoprodutos tóxicos exceda um valor mínimo capaz de produzir dano irreversível à célula. Supondo que a concentração de FS e a concentração de oxigênio molecular sejam suficientes e uniformemente distribuídas no tecido alvo, a morte celular dependerá exclusivamente da dose de luz entregue ao tecido.

Em modelos animais sadios, como o fígado de rato, observa-se que as células apresentam um valor único de $D_{t h}$. Isto é evidenciado quando se aplica a TFD em tecidos normais, onde se observa através de microscopia óptica que existe uma linha bem definida entre a região necrosada e a região preservada do tecido normal, após a ação fotodinâmica. Nesta interface, chamada de profundidade de necrose, pode-se dizer que a $D_{t h}$ foi alcançada. Definimos $g\left(D_{t h}\right)$ como uma função cuja interpretação física é a seguinte: a $g\left(D_{t h}\right) d D_{t h}$ representa a fração de células em um dado volume tumoral com dose limiar entre $D_{t h}$ e $D_{t h}+$ $d D_{t h}$. Assim, podemos representar a população de células de um tecido normal em função de sua dose limiar por uma função de Dirac, descrita como:

$$
g\left(D_{t h}\right)=A \cdot \delta\left(D(z)-D_{t h}\right)
$$

Na Equação 3.1, $D(z)$ é a dose de luz que varia em função da profundidade $(z), A$ é uma constante relacionada com a densidade de células e $D_{t h}$ representa a dose limiar do tecido normal. A $D_{t h}$ tem como unidade o $\mathrm{J} / \mathrm{cm}^{2}$ e expressa a quantidade de fótons que devem ser entregues a uma célula para causar sua morte. Integrando-se (3.1) no intervalo $[0,+\infty]$ obtemos a identidade de normalização relacionada à interpretação estatística da $g(D t h)$.

$$
\int_{0}^{+\infty} g\left(D_{t h}\right) d D_{t h}=1
$$


Nesse modelo de tecido, as heterogeneidades do tumor, como a presença de vasos sanguíneos, não são consideradas. Além disso, supõe-se que o FS e o oxigênio molecular estão presentes nas células neoplásicas, distribuídos homogeneamente no tecido e em concentração suficiente para a ação fotodinâmica. A dose de luz aplicada no tecido alvo será o parâmetro determinante na morte celular e na resposta tumoral. Após a primeira iluminação da lesão, as células que receberam quantidade de fótons suficiente para atingir a dose de luz superior à sua dose limiar $\mathrm{D}_{\text {th }}$ foram mortas. Entretanto, as células que receberam dose de luz inferior ao $\mathrm{D}_{\mathrm{th}}$, sobreviverão e reconstituirão o tecido. Em geral, o modelo de penetração da luz no tecido biológico é, numa aproximação aceitável, baseado na Lei de Beer-Lambert que pode ser descrita como $^{7}$ :

$$
I(z)=I_{0} e^{-\mu z}
$$

onde a $I(z)$ é a intensidade luminosa na profundidade $z, I_{0}$ a intensidade da luz na superfície e $\mu$ representa o coeficiente efetivo de atenuação da luz no tecido, que depende do tipo de tecido e de suas propriedades de absorção e espalhamento da luz utilizada. O modelo de distribuição de luz no tecido biológico introduzido por Grossweiner et al. utiliza-se da Lei de Beer-Lambert para relacionar a dose de luz (fluência de luz) em função da posição espacial com as propriedades ópticas do tecido e a dose de luz aplicada na superfície. A distribuição da dose de luz em função da profundidade $D(z)$ é descrita pela expressão dada pela equação $(3.4)^{7,11,23}$.

$$
D(z)=D_{0} e^{-\mu z}
$$

onde $D_{0}$ é a dose de luz entregue na superficial do tumor dada por $D_{0}=I_{0} t\left(\mathrm{~J} / \mathrm{cm}^{2}\right)$. A dose de luz entregue ao tecido biológico decresce em função da profundidade, como mostra a Figura 3(a). Isto significa que para cada posição em profundidade a dose de luz entregue é menor, bem como a quantidade de danos causados nas células. O padrão de distribuição da luz no tecido biológico depende das características ópticas do tecido; estas características determinam a absorção e o espalhamento dos fótons 
que penetram no tecido biológico. A quantidade de FS também pode alterar a capacidade de absorção do tecido.

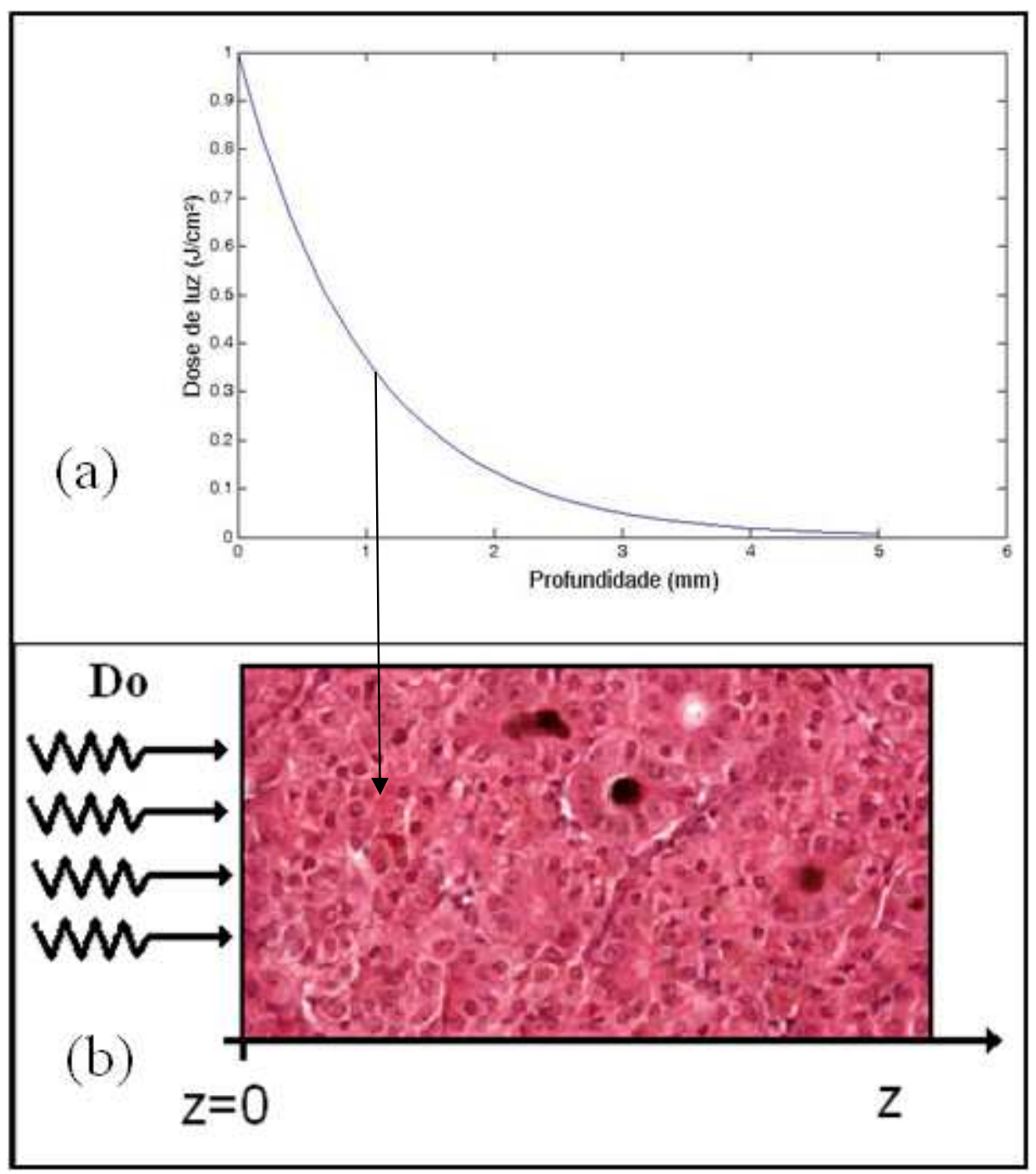

Figura 3 - (a) Decréscimo da dose de luz em função da profundidade para um tecido biológico utilizando-se o modelo de distribuição de luz baseado na Lei de Beer-Lambert. Os parâmetros utilizados são arbitrários. (b) Ilustração da entrega da dose de luz durante a sessão da TFD no modelo tumoral. Considera-se nesse modelo apenas a propagação da luz e os efeitos causados pela ação fotodinâmica em função da profundidade do tecido $z$.

A dose de luz é entregue à superfície do tecido, como mostra a Figura 3(b). A fração de células que receber valor de $D_{t h}<D(z)$ morrerá; a fração de células que apresentar dose limiar superior sobreviverá. Desta forma, a fração de morte $f(D(z))$ causada pela TFD, como 
função da dose de luz entregue para um tecido normal, que apresenta um valor bem definido de $D_{t h}$, pode ser obtida. Esta função fração de morte pode ser representada pela expressão:

$$
f(D(z))=\left\{\begin{array}{l}
0, D(z)<D_{t h} \\
1, D(z) \geq D_{t h}
\end{array}\right.
$$

A fração de morte em função da profundidade $(f(z))$ para uma dada distribuição de $D_{t h}$ após a aplicação da TFD pode ser obtida pela função cumulativa de $g(D t h)$. Obtemos $f(z)$ quando relacionamos a distribuição da dose de luz entregue ao tecido com a distribuição de dose limiar do tecido através da equação (3.6).

$$
f(z)=\int_{0}^{D(z)} g\left(D_{t h}\right) d D_{t h}
$$

Para cada posição $z$, será entregue uma dose de luz $D(z)$, todas as células que apresentarem $D_{t h}<D(z)$ morrerão. Contudo, $D_{t h}$ é um valor constante para o tecido sadio, tornando a fração de morte dependente apenas da profundidade. Então, de acordo com o modelo de distribuição de luz no tecido biológico, a profundidade até a qual $D(z)$ é maior que $D_{t h}$ será $z_{t h}=\frac{1}{\mu} \ln \frac{D_{0}}{D_{t h}}$, e a fração de morte em função da posição pode ser definida como uma função cumulativa da função Delta de Dirac. Nessas condições,

$$
f(z)=\left\{\begin{array}{l}
1, z<\frac{1}{\mu} \ln \frac{D_{0}}{D_{t h}} \\
0, z \geq \frac{1}{\mu} \ln \frac{D_{0}}{D_{t h}}
\end{array}\right.
$$

De acordo com esta equação, todas as células presentes na região entre a superfície $(z=0)$ e $z_{t h}$ serão mortas após a sessão da TFD, ou seja, a morte celular foi máxima, como mostra a Figura 4(a). A morte celular de acordo com o modelo teórico é dada pela $f(z)$, que determina a interface da região do tecido necrosada e do tecido sadio; esta linha é bem 
definida e pode ser traçada paralela à superfície, na profundidade $z_{t h}$, como mostra a Figura 4(a). Entretanto, observa-se em experimentos com modelos animais que esta linha não é retilínea, pois a intensidade de luz não se distribui de forma perfeitamente homogênea no tecido. A variação da profundidade de necrose $z_{t h}$ sugere que distribuição de $D_{t h}$ para um tecido normal não é um valor unitário e sim uma distribuição estreita de $D_{t h}$. Sendo assim, a fração de morte pode ser expressa por uma função escada, mostrada na Figura 4(b).

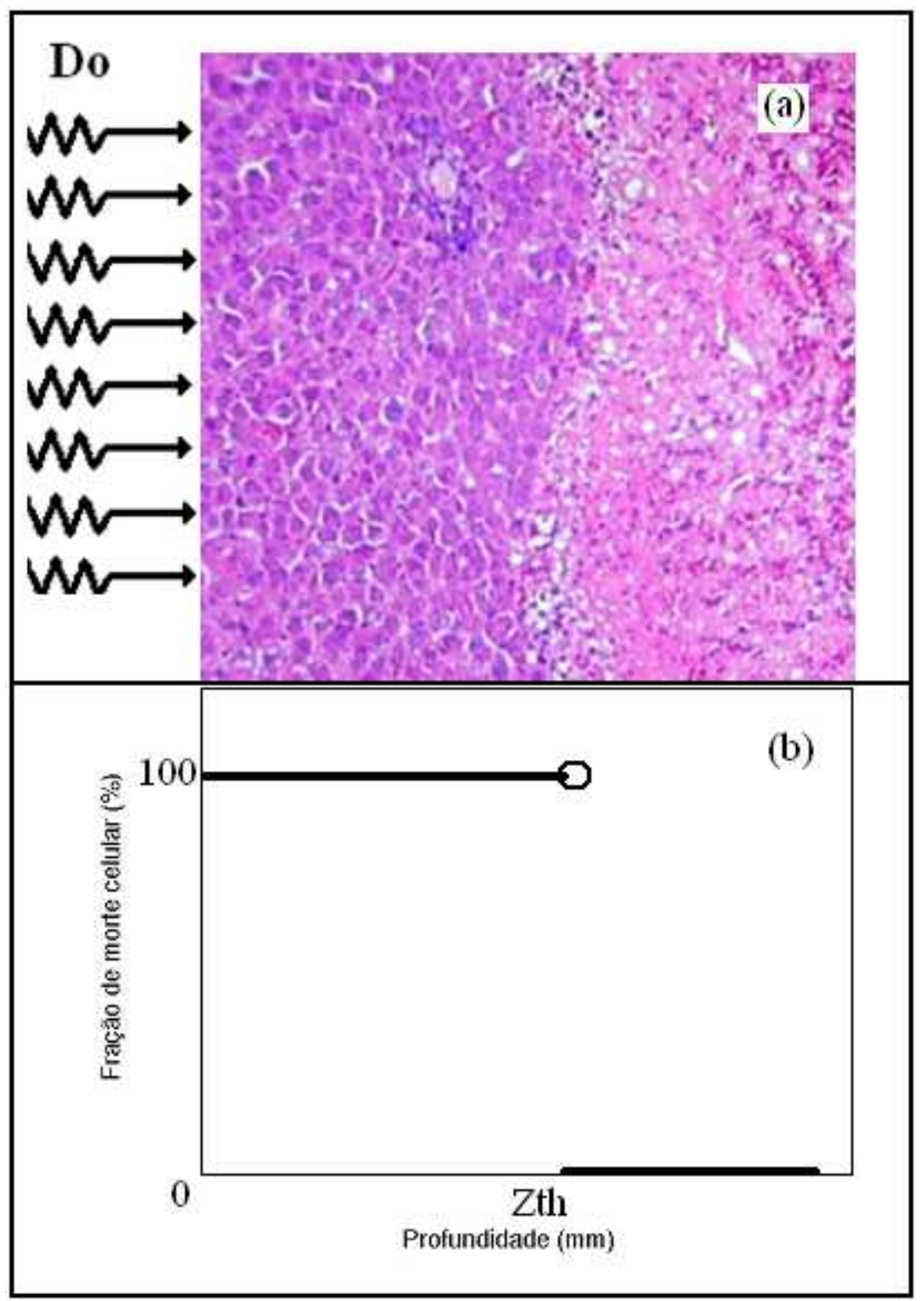

Figura 4 - (a) Imagem de uma lâmina histológica de fígado de rato (100x) após a sessão da TFD com iluminação superficial, com células coradas em HE. Pode-se observar que à esquerda da profundidade de necrose as células estão mortas. (b) Representação gráfica da fração de morte para um tecido sadio, $\boldsymbol{z}_{\boldsymbol{t h}}$ representa a profundidade de necrose. 
Para um tecido com dadas características, a aplicação da TFD em várias sessões causaria necrose com características e profundidade semelhantes em todas as sessões. Porém, mesmo se tratando de tecidos normais, observa-se uma variação da resposta tecidual à TFD utilizando-se os mesmos parâmetros de aplicação. Entretanto, o conceito de dose limiar vem sendo utilizado na dosimetria da TFD, inclusive em tecidos neoplásicos. Contudo, para casos em que os tumores e lesões neoplásicas apresentem baixo grau de diferenciação (o que significa uma alta variedade celular) e desta forma, diferentes respostas à TFD, ainda existe a necessidade de investigação das consequiências do tratamento em múltiplas sessões, visando torná-la uma terapia de resultados mais previsíveis.

Existem vários estudos que relatam a existência de uma variedade de células num mesmo tumor. Na literatura encontram-se alguns estudos que investigam a causa dessa diferença na resistência à TFD apresentada por tais células ${ }^{18,27}$. Além disso, existe um grande interesse no entendimento dos efeitos causados pela variabilidade de dose limiar na resposta do tecido neoplásico à ação fotodinâmica. No modelo proposto a seguir a resposta tumoral é simulada utilizando-se o conceito de distribuição de dose limiar em um tecido neoplásico.

\subsection{Um modelo com variabilidade de dose limiar para a Terapia Fotodinâmica}

Sabe-se que as células que compõem um tecido neoplásico apresentam baixo grau de diferenciação, o que lhes confere heterogeneidade em termos de morfologia, fase de diferenciação e metabolismo. Esta variabilidade celular existe mesmo que o tumor seja derivado de uma única célula neoplásica ${ }^{14,20,28}$. Baseado nesta heterogeneidade celular supõese que, para um tumor contendo células com diferentes graus de diferenciação, exista uma variação na resistência à TFD que implica em uma variabilidade de $D_{t h}$. Sendo um tumor um sistema biológico, é plausível representar a variabilidade da dose limiar da população celular tumoral por uma distribuição Gaussiana; supondo que para dose de luz igual a zero não haverá morte celular. Desta forma, numa unidade de volume tumoral, o número de células que apresentam dose limiar específica $D_{t h}$, pode ser representado por uma distribuição Gaussiana modificada de $D_{t h}$. 


$$
g\left(D_{t h}\right)=A D_{t h}^{2} e^{\frac{-D_{t h}^{2}}{\sigma_{0}^{2}}}
$$

$\mathrm{Na}$ Equação (3.8), $A$ é uma constante de normalização que representa a densidade de células do tecido tumoral, $\sigma_{0}$ (sigma zero, antes da TFD) representa a largura da distribuição de $D_{t h}$ para a população de células do tumor original. A Figura 5 mostra a representação gráfica desta distribuição Gaussiana modificada. Para valores maiores de $\sigma_{0}$ a curva se desloca para a direita, o que implica em maior heterogeneidade celular, aumentando de maneira geral a $D_{t h}$ da população celular. Neste caso, assumiremos neste modelo o valor de $\sigma_{0}=1$ para o tumor original com o intuito de simplificar o entendimento do modelo; sendo assim, a $D_{t h}$ será expressa em unidades de $\sigma_{0}$. A largura da curva $\left(\sigma_{0}\right)$ é representada pela seta preta na Figura 5. Posteriormente, este parâmetro irá caracterizar a variação da resistência do tecido à TFD.

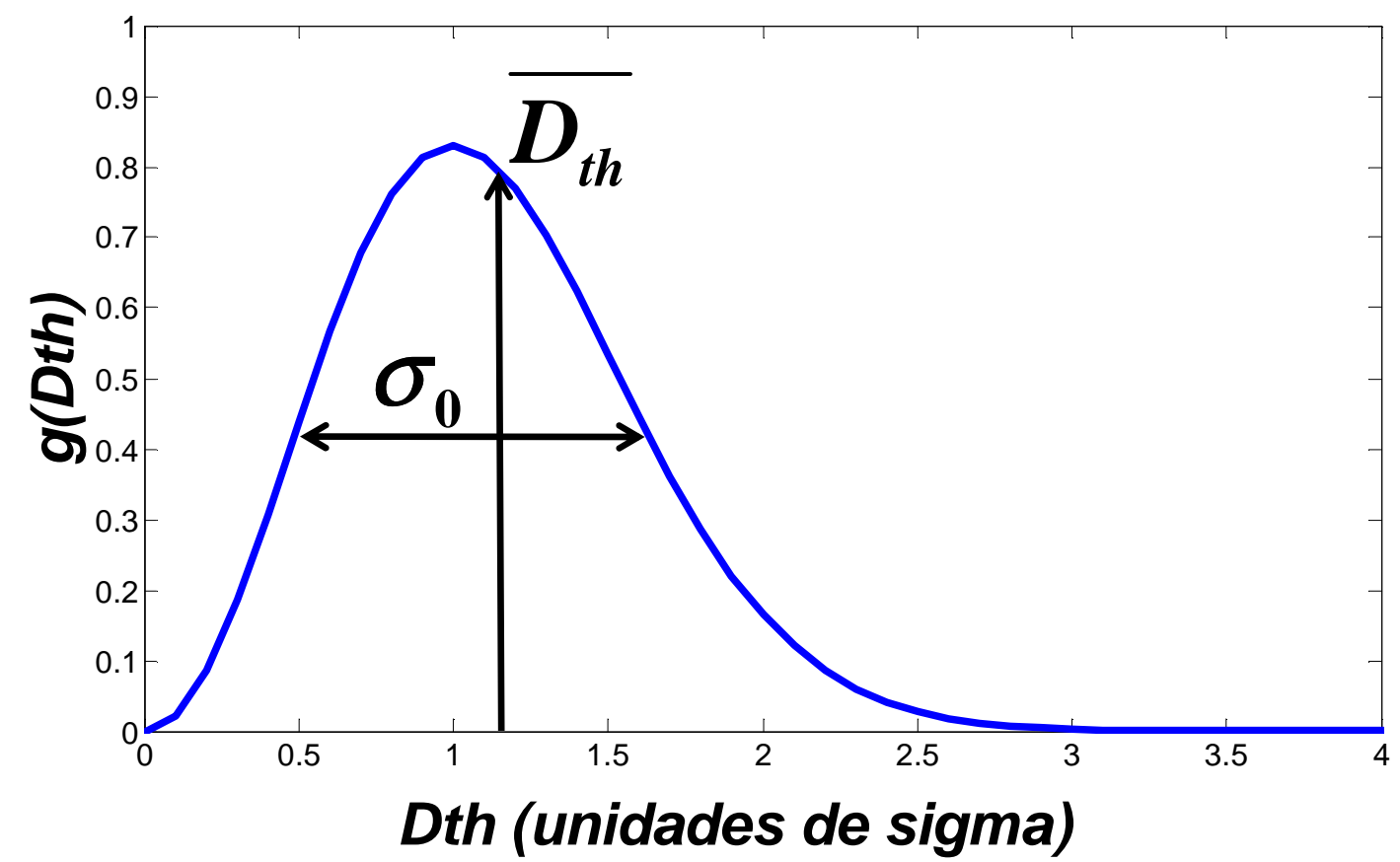

Figura 5 - Representação gráfica da curva de distribuição Gaussiana modificada de dose limiar $\left(g\left(D_{t h}\right)\right)$. A largura da curva para o tumor original vale $1 \sigma_{0}$, de forma que o valor da dose limiar será apresentado em unidades de sigma $\left(\sigma_{0}\right)$ para simplificar a interpretação do modelo. 
De acordo com o modelo proposto, existe uma diversidade de valores de $D_{t h}$ e a fração de células que apresenta dose limiar no intervalo entre $\left(D_{t h}\right)$ e $\left(D_{t h}+d D_{t h}\right)$, sendo $d D t h$ o incremento em $D_{t h}$, pode ser calculada através da razão $R$, apresentada na Equação (3.9).

$$
R=\frac{\mathrm{g}\left(\mathrm{D}_{\mathrm{th}}\right) \mathrm{dD_{ \textrm {th } }}}{\int_{0}^{\infty} \mathrm{g}\left(\mathrm{D}_{\mathrm{th}}\right) \mathrm{dD} \mathrm{D}_{\mathrm{th}}}
$$

A densidade de células (quantidade de células/volume tumoral) é obtida através da integral da função $g\left(D_{t h}\right)$, e a normalização da $g\left(D_{t h}\right)$ é feita de acordo com os princípios da distribuição de probabilidade ${ }^{29}$. Partindo da condição em que $100 \%$ das células apresentam valor de dose limiar igual ou maior que zero, podemos representar esta propriedade da distribuição de $D_{t h}$ através da Equação (3.10).

$$
\int_{0}^{\infty} g\left(D_{t h}\right) d D_{t h}=1
$$

A partir da equação 10 obtém-se a constante de normalização $A$.

$$
A=\frac{4 \sigma_{0}^{-3}}{\sqrt{\pi}}
$$

A distribuição de dose limiar pode ser reescrita na forma normalizada pela expressão a seguir,

$$
g\left(D_{t h}\right)=\frac{4 \sigma^{-3}}{\sqrt{\pi}} D_{t h}^{2} e^{\frac{-D_{t h}^{2}}{\sigma_{0}^{2}}}
$$

De acordo com a função (3.12), neste modelo de tumor existe uma pequena parcela da população celular que apresenta valores de $D_{t h}$ tendendo a infinito (muito acima do $\overline{D t h}$ ). Conseqüentemente, nas simulações realizadas a seguir, não ocorrerá erradicação total das células neoplásicas após a ação da TFD com dose finita de luz. Estas células remanescentes 
causam o recrescimento tumoral. Como só existem valores de $D_{\text {th }}$ positivos, a dose limiar média da distribuição $\left(\overline{D_{t h}}\right)$ pode ser obtida por meio da integração de (3.12) no intervalo $[0, \infty]$, como descrito na Equação (13).

$$
\overline{D_{t h}}=\int_{0}^{\infty} D_{t h} g\left(D_{t h}\right) d D_{t h}
$$

Disto resulta a Equação (3.14), que relaciona a dose limiar média e a largura da distribuição de $D_{t h}$ :

$$
\overline{D_{t h}}=\frac{2}{\sqrt{\pi}} \sigma_{0} .
$$

De acordo com o modelo proposto, a dose limiar média $\overline{D_{t h}}$ é um parâmetro que está relacionado com a resistência tumoral à TFD no aspecto macroscópico: quanto maior o $\overline{D_{t h}}$ do tecido, mais difícil erradicá-lo com a TFD. Adicionalmente, a relação entre o $\overline{D_{t h}}$ e a largura da curva $\sigma_{0}$ será útil na avaliação da variação da resistência do modelo de tumor após a sessão da TFD. Um alto valor de $\overline{D_{t h}}$ significa um alto valor de $\sigma_{0}$ e isso implica em altas doses de luz para promover a erradicação das células tumorais. Portanto, supondo que ocorra um aumento no valor de $\sigma$ num tumor recidivo ou recrescido, após a TFD, além de não causar eliminação total do tumor, a ação fotodinâmica pode promover uma seleção das células mais resistentes. Isto poderia causar o surgimento de um tumor recidivo que apresenta maior resistência à TFD. 


\subsection{Fração de morte após a primeira sessão da TFD}

Para simplificação do modelo, apenas consideraremos a propagação da luz e os efeitos causados pela TFD na distribuição de dose limiar no eixo $z$, que representa a posição em profundidade, como mostra a Figura 2(b). A dose de luz superficial $\left(D_{0}\right)$ é entregue na superfície, para $z=0$, e se propaga através do tecido, decrescendo exponencialmente como função da profundidade $z$.

Neste modelo, simulamos um tumor que apresenta densidade de células arbitrária. Todas as células contêm FS em dose necessária para que a morte celular ocorra através da ação fotodinâmica, sendo o único limitante a dose de luz. É importante lembrar que o oxigênio molecular é considerado como estando presente nas células em quantidade suficiente para causar a morte celular, e que o consumo do FS e do oxigênio molecular durante o processo fotodinâmico são desprezados neste modelo. A única variável para as células desse modelo tumoral inicial é a dose limiar de luz. Portanto, para uma dada profundidade $z$, as células que apresentarem $D(z)>D_{t h}$ serão mortas pela ação fotodinâmica. Por outro lado, aquelas que apresentarem $D(z)<D_{t h}$ sobreviverão e proliferarão, reconstituindo o tecido tumoral. Após algum tempo, surge uma segunda geração de células, formadas por uma população com distribuição de dose limiar diferente da população de células do tumor original.

Antes da primeira sessão da TFD, consideramos que a densidade de células e a distribuição de dose limiar $g\left(D_{t h}\right)$ não variam em função da profundidade $z$. Portanto, a morte celular causada pela TFD dependerá das características ópticas do tecido, da dose de luz $D(z)$ e da distribuição de dose limiar $\left(g\left(D_{t h}\right)\right)$. A fração de morte celular em função da profundidade do tecido pode ser encontrada através da função cumulativa da distribuição Gaussiana modificada de $D_{t h}$. Conseqüentemente, a fração de morte para cada posição $z$ após a primeira sessão da TFD, pode ser obtida através da integração da $g\left(D_{t h}\right)$ no intervalo entre zero e $D(z)$, apresentada a seguir pela equação (3.15).

$$
f_{1}(z)=\int_{0}^{D(z)} g\left(D_{t h}\right) d D_{t h}
$$


sendo $g\left(D_{t h}\right)$ como descrito em (3.8). A solução desta integral é:

$$
f_{1}(z)=\frac{4}{\sqrt{\pi}}\left\{-\frac{D(z)}{2 \sigma_{0}} e^{-\frac{D(z)^{2}}{\sigma_{0}^{2}}}+\frac{\sqrt{\pi}}{4} \operatorname{erf}\left(\frac{D(z)}{\sigma_{0}}\right)\right\} .
$$

onde $\operatorname{erf}$ representa a função erro, que foi criada para poder calcular a integral da distribuição normal. A fração de morte $f_{1}(z)$ representa o percentual das células que foram mortas em cada profundidade $z$, após a iluminação na primeira sessão da TFD. Como descrito anteriormente, estamos expressando as doses em unidades de sigma $\sigma_{0}$. Para avaliar o efeito da dose de luz no modelo tumoral, realizou-se uma simulação da fração de morte $f_{1}(z)$ utilizando diferentes valores de dose de luz superficial $\left(D_{0}=1 \sigma_{0}, 2 \sigma_{0}, 3 \sigma_{0} \ldots\right)$ que pode ser vista na Figura 6, lembrando que $\sigma_{0}=1$.

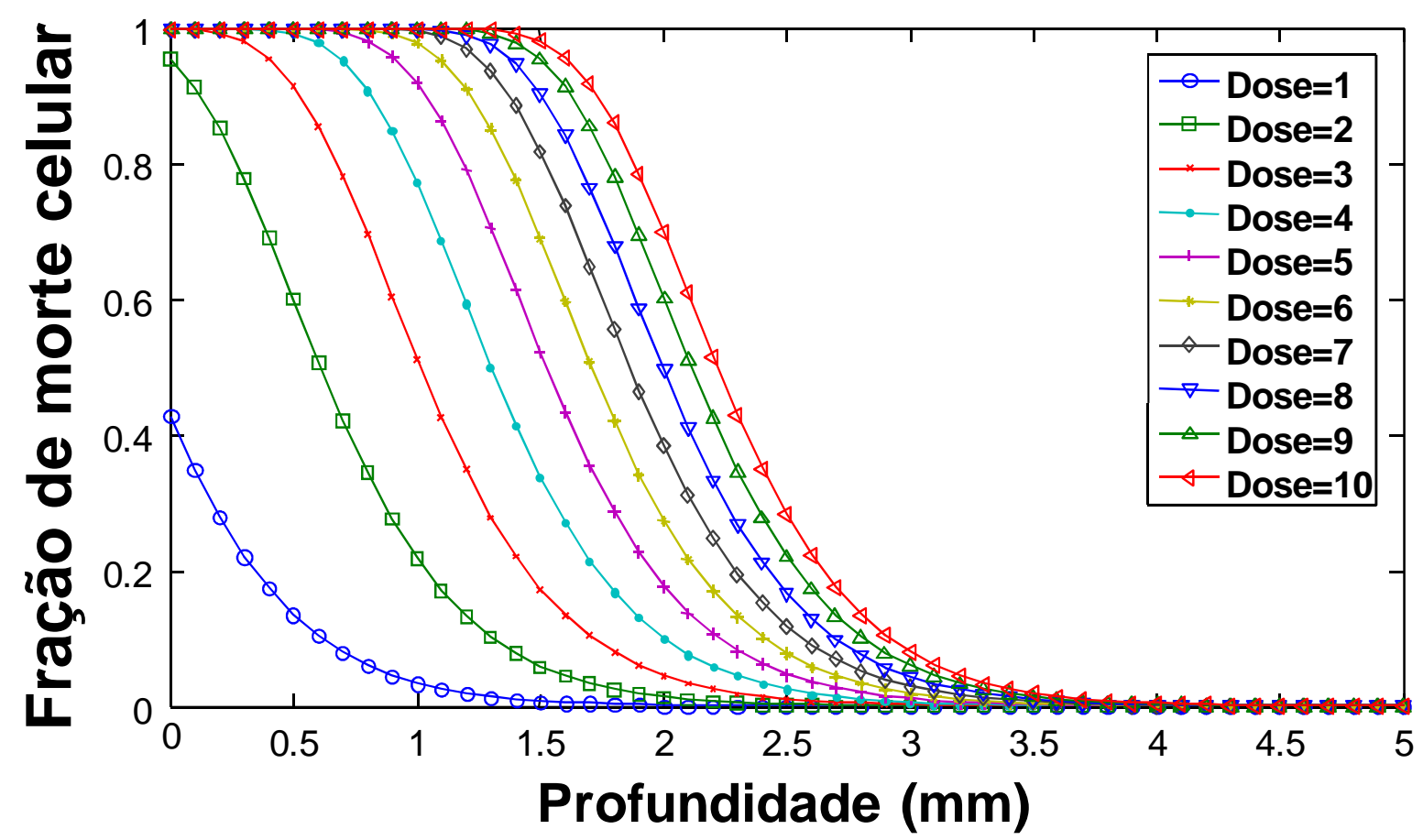

Figura 6 - Representação gráfica da simulação da fração de morte em função da profundidade (3.16) para diferentes valores de dose superficial $\left(D_{0}=1 \sigma_{0}, 2 \sigma_{0}, 3 \sigma_{0} \ldots 10 \sigma_{0}\right)$. 
Observa-se no gráfico da Figura 6 que a fração de morte celular decresce em função da profundidade, apresentando um padrão característico da função erro (erf); à medida que a dose de luz entregue ao tecido decresce apenas as células de $D_{t h}$ menor morrem, as células mais resistentes sobrevivem. A fração de morte para dose $1 \sigma_{0}$ não ultrapassa $50 \%$ mesmo na superfície do tecido. Isto era esperado, já que em linhas gerais, menos de 50\% da distribuição de células recebeu dose de luz suficiente para morrer. Nestas condições, considerando-se que na profundidade onde a fração de morte foi inferior a 5\% o efeito fotodinâmico foi mínimo ou não ocorreu, pode-se considerar uma extensão ou margem de necrose para cada caso. Quando se utiliza doses mais elevadas, como a $D_{0}=10 \sigma_{0}$, a erradicação ocorre até certa profundidade; contudo, como sempre haverá uma fração de células que apresentaram $D_{\text {th }}$ muito alto e sobreviveram, estas células formarão um novo tumor. No entanto, o novo tumor apresentará uma nova distribuição de $D_{t h}$, que varia em função da profundidade $z$. Isto ocorre porque a seleção das células resistentes, causada pela primeira sessão da TFD, acontece em diferentes níveis dependendo da profundidade.

\subsection{Recrescimento do tumor após a $1^{\circ}$ sessão da TFD e fração de morte após a $2^{\circ}$ sessão}

Nesta etapa, considera-se que as células que sobreviveram à primeira sessão da TFD tenham se proliferado e formado um novo tumor (através do recrescimento tumoral). Este novo tumor apresenta mesmas dimensões, mesma geometria e mesma densidade de células do tumor original (esta consideração, embora não represente a realidade, facilita a análise das variações de $D_{t h}$ previstas no modelo). Entretanto, a população do tumor recidivo apresenta características diferentes em termos de distribuição de dose limiar para cada posição (z). Esta variação da distribuição de limiar de dose pode ser evidenciada através da dose limiar média em função da profundidade $\left(\overline{D^{(1)} t h(z)}\right)$ após a primeira sessão da TFD seguida de recrescimento tumoral. 
As características biológicas da população de células do tumor recrescido serão diferentes da população de células do tumor original. No caso do modelo teórico, esta diferença será expressa pela nova distribuição de dose limiar $\left(g^{(1)}\left(D_{t h}, z\right)\right)$, a qual após a primeira sessão da TFD passa a ser dependente da profundidade $z$, o que não se assumia inicialmente no modelo. A distribuição de dose limiar para a população desta nova geração de células é dada por

$$
g^{(1)}\left(D_{t h}, z\right)=\left\{\begin{array}{ll}
0 & D_{t h} \leq D(z) \\
A . D_{t h}^{2} e^{\frac{-D_{t h}^{2}}{\sigma(z)^{2}}} & D_{t h}>D(z)
\end{array},\right.
$$

onde $A$ é uma constante. Esta nova distribuição é semelhante à original, porém truncada de forma a remover aquelas células que já morreram. A dose limiar média era constante e espacialmente independente no tumor original; no tumor recrescido, por sua vez, passa a variar em função da profundidade $(z)$. Esta variação da dose limiar média depende da dose de luz entregue ao tumor e da distribuição de $D_{t h}$ inicial, e é calculada através da Equação (3.18).

$$
\overline{D^{(1)} t h(z)}=\frac{\int_{0}^{\infty} D_{t h} \mathrm{~g}^{(1)}\left(\mathrm{D}_{\mathrm{th}}\right) \mathrm{d} \mathrm{D}_{\mathrm{th}}}{\int_{0}^{\infty} \mathrm{g}^{(1)}\left(\mathrm{D}_{\mathrm{th}}\right) \mathrm{d} \mathrm{D}_{\mathrm{th}}}
$$

Reescreve-se a equação 3.18 , normalizando a nova distribuição de $D_{\text {th }}$ para simular o efeito sobre uma quantidade de células equivalente a quantidade de células do tumor original, porém mantendo a dose limiar média das células do novo tumor para cada profundidade (z). Portanto, utilizando as relações entre a condição de contorno e a equação da média entre $g^{(1)}\left(D_{\text {th }}\right)$ e $g\left(D_{\text {th }}\right)$, obtém-se:

$$
\overline{D^{(1)} t h(z)}=\frac{\int_{0}^{\infty} D_{t h} \mathrm{~g}\left(\mathrm{D}_{\mathrm{th}}\right) \mathrm{dD}_{\mathrm{th}}-\int_{0}^{D(z)} D_{t h} \mathrm{~g}\left(\mathrm{D}_{\mathrm{th}}\right) \mathrm{d} \mathrm{D}_{\mathrm{th}}}{\int_{0}^{\infty} \mathrm{g}\left(\mathrm{D}_{\mathrm{th}}\right) \mathrm{dD}_{\mathrm{th}}-\int_{0}^{D(z)} \mathrm{g}\left(\mathrm{D}_{\mathrm{th}}\right) \mathrm{d} \mathrm{D}_{\mathrm{th}}} .
$$


Por fim, aplicam-se as equações (3.10), (3.13), e (3.15) na equação (3.16), resultando em

$$
\overline{D^{(1)}{ }_{t h}(z)}=\frac{\frac{2 \sigma_{0}}{\sqrt{\pi}}-M(z)}{1-f_{1}(z)}
$$

onde $M(z)=\int_{0}^{D(z)} D_{t h} g\left(D_{t h}\right) d D_{t h}$, que está relacionada com a fração de morte causada pela primeira sessão da TFD. Esta integral pode ser resolvida usando conceitos da teoria de probabilidade. O crescimento da $\overline{D_{t h}(z)}$ implica num aumento macroscópico da resistência tumoral às novas sessões da TFD. Para caracterizar esse aumento na nova distribuição de $D_{t h}$ relacionamos $\overline{D^{(1)}{ }_{t h}(z)}$ com a largura das gaussianas em cada profundidade $(z)$ de acordo com a Equação 3.6, como mostra a equação (3.21):

$$
\sigma^{1}(\mathrm{z})=\frac{\sqrt{\pi}}{2} \overline{D^{(1)} t h(z)}
$$

onde $\sigma^{1}(z)$ representa o largura da curva em função da profundidade para o tumor recidivo e depende de $\sigma_{0}$ de acordo com (3.20). Em outras palavras, consideramos que a distribuição Gaussiana é restabelecida em cada posição, porém com a nova dose limiar média $\overline{D^{(1)}{ }_{t h}(z)}$, estabelecida pela distribuição truncada. Assim, a nova distribuição é na verdade dada por $g^{(1)}\left(D_{t h}, z\right)=A^{\prime} D_{t h}^{2} e^{\frac{-D_{t h}^{2}}{\left(\sigma^{1}(z)\right)^{2}}}$. Isto significa que a largura da Gaussiana é modificada, e será dependente da posição. A simulação de $\sigma^{I}(z)$ (Equação (3.21)) para três diferentes doses superficiais $\left(D_{0}=1 \sigma_{0}, 1.3 \sigma_{0}\right.$ e $\left.1.6 \sigma_{0}\right)$ é mostrada na Figura 7 . De acordo com o modelo teórico, a dose $1,6 \sigma_{0}$ causa um aumento significativo dos valores de $\sigma^{1}(z)$ na superfície. Tal aumento ocorre porque na região próxima da superfície apenas células de alto valor de $D_{t h}$ sobreviveram, e é a partir delas que o tecido foi reconstituído. Nestas circunstâncias, uma nova sessão de TFD com a mesma dose causará menor fração de morte nas proximidades da superfície, se mantida a mesma dose de luz. 


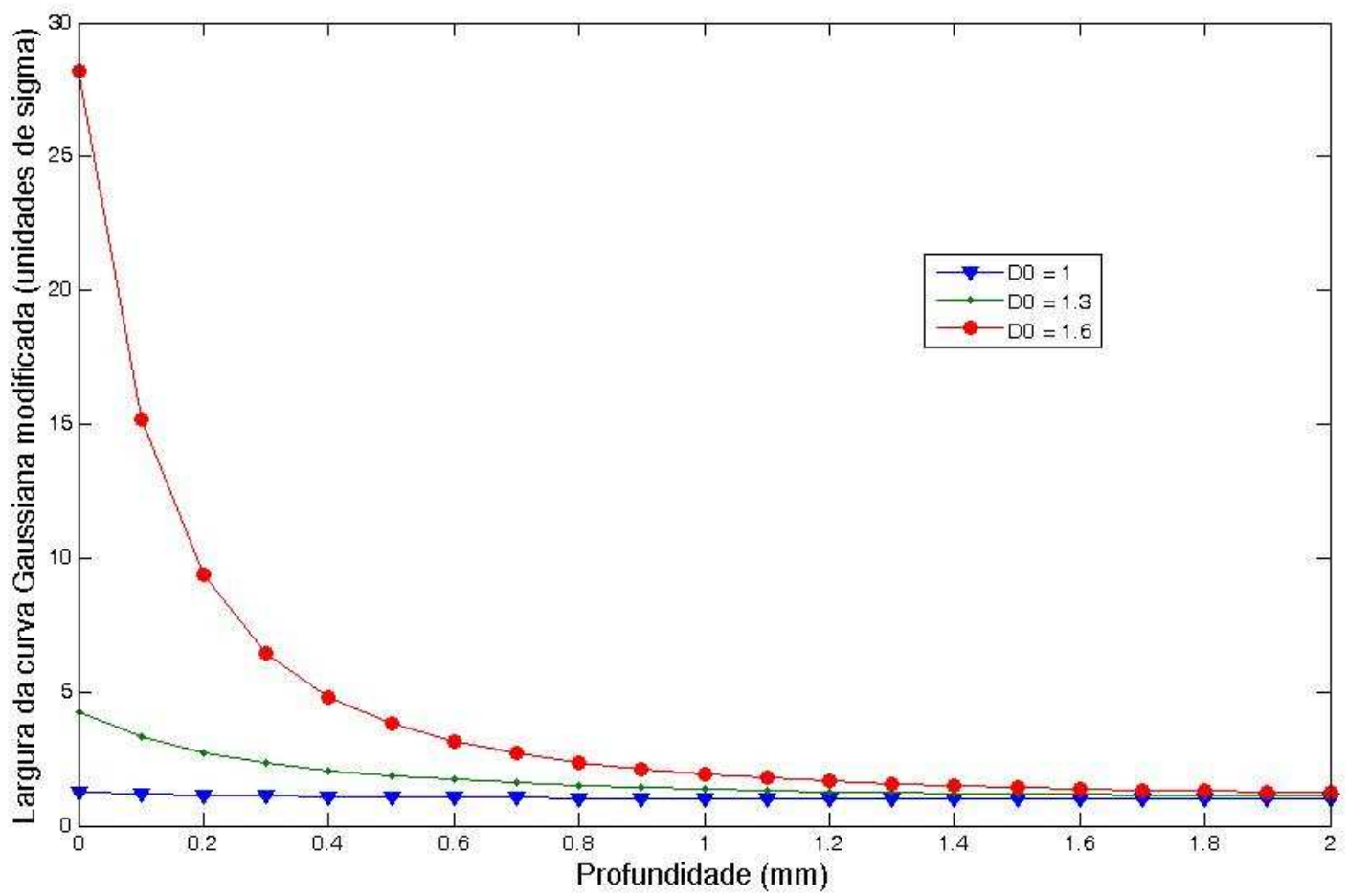

Figura 7 - Largura da curva Gaussiana $\boldsymbol{\sigma}^{I}(\mathbf{z})$ em função da profundidade do tumor recidivo. As doses utilizadas na simulação foram $D_{0}=1 \sigma_{0}, 1.3 \sigma_{0}$ e $1.6 \sigma_{0}$.

A Figura 7 mostra que para uma pequena variação de dose superficial, uma grande variação da resistência do tecido tumoral é causada. Em particular, a dose $1 \sigma_{0}$ não causa grandes alterações nas características do tecido, isto porque, como vimos na Figura 6, esta dose causa fração de morte inferior a $50 \%$ na superfície.

Para avaliar a resposta do modelo tumoral à segunda sessão da TFD realizou-se uma simulação utilizando-se as mesmas doses de luz da primeira sessão, assumindo que no tumor recidivo ocorra variação da largura da distribuição de $D_{t h}$ (agora dependente da profundidade z). Para obter a fração de morte após a segunda sessão da TFD, utilizamos a função cumulativa integrando $g^{(1)}\left(D_{t h}, z\right)$, como mostra a equação 3.22 .

$$
f_{2}\left(D_{t h}, z\right)=\int_{0}^{D(z)} \mathrm{g}^{(1)}\left(\mathrm{D}_{\mathrm{th}}, \mathrm{z}\right) \mathrm{dD}_{\mathrm{th}}
$$


A solução dessa integral é semelhante à solução da integral da distribuição de $D_{t h}$ inicial e determina a fração de células mortas após a segunda aplicação, que é expressa por (3.23),

$$
f_{2}(z)=\frac{4}{\sqrt{\pi}}\left\{-\frac{D(z)}{2 \sigma^{I}(z)} e^{-\frac{D(z)^{2}}{\left(\sigma^{1}(z)\right)^{2}}}+\frac{\sqrt{\pi}}{4} \operatorname{erf}\left(\frac{D(z)}{\sigma^{I}(z)}\right)\right\}
$$

onde $\sigma^{l}(z)$ (Equação 3.21) representa largura das novas distribuições de $D_{t h}$ após a $1^{\circ}$ TFD, em função da profundidade.

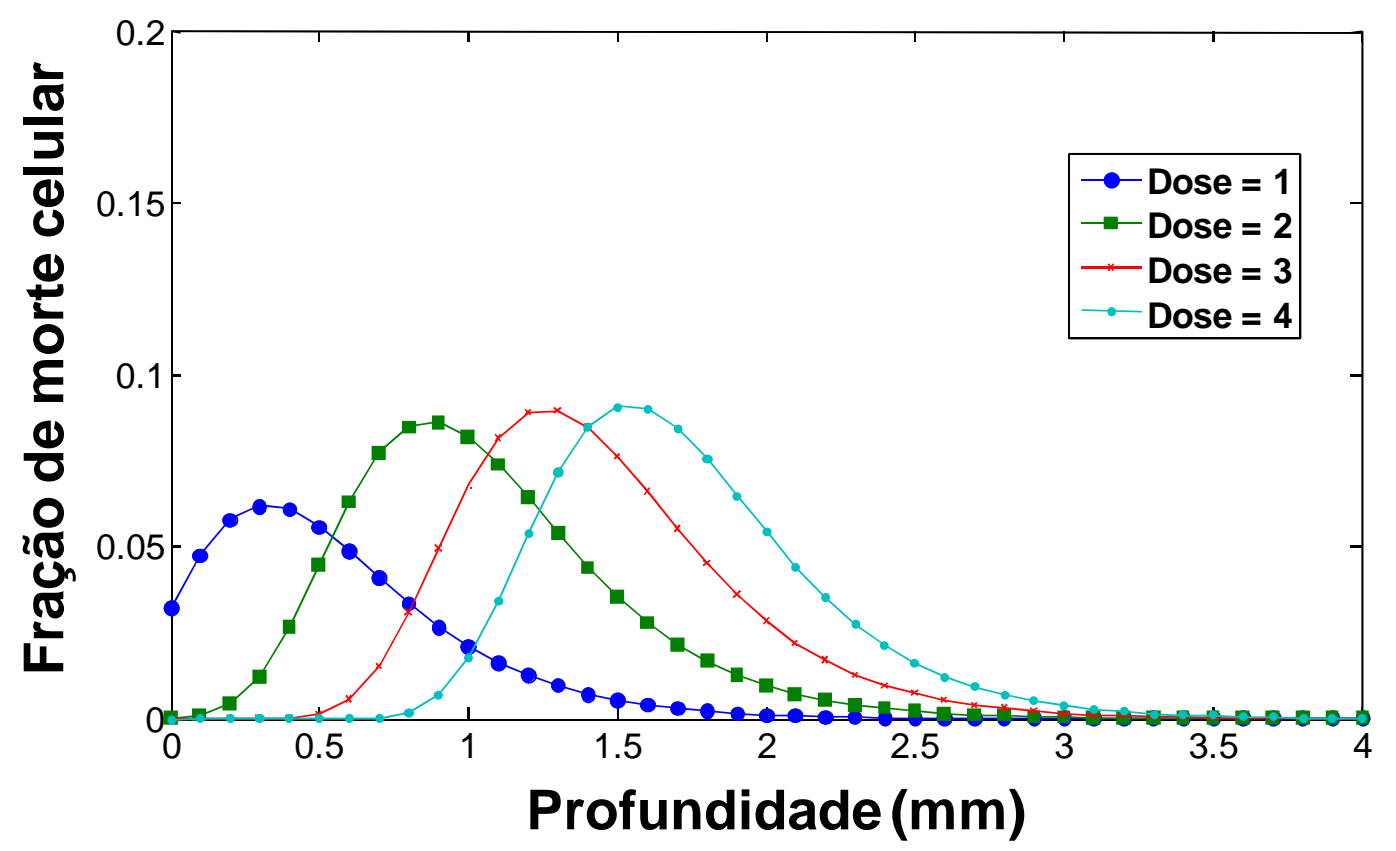

Figura 8 - Representação gráfica da simulação da fração de morte em função da profundidade (3.23) para a segunda sessão da TFD com quatro das doses superficiais utilizadas na primeira sessão $\left(D_{0}=1 \sigma_{0}\right.$, $2 \sigma_{0}, 3 \sigma_{0}$ e $\left.4 \sigma_{0}\right)$

A Figura 8 mostra que a fração de morte da segunda sessão não ultrapassa $10 \%$ e é apresenta um padrão espacial diferente, não permitindo verificar uma nova borda de necrose. Essa simulação mostra uma redução acentuada da resposta tumoral à ação fotodinâmica. Tomando como exemplo a dose $1 \sigma_{0}$ : na primeira sessão da TFD, ela promove $50 \%$ de morte 
celular, enquanto que na segunda sessão promove apenas $3 \%$ de fração de morte na superfície. Pode-se notar que doses maiores não causaram morte celular na superfície, isso porque as células que reconstituíram aquela região apresentam altos valores de $D_{t h}$. À medida que aumenta a profundidade, a dose de luz entregue diminui; no entanto, a $D_{t h}$ das células diminui, provocando um pequeno aumento na fração de morte a certa profundidade. Portanto, de acordo com o modelo teórico, sucessivas sessões da TFD utilizando a mesma dose de luz serão cada vez menos efetivas, diminuindo a eficácia da técnica até uma eventual inviabilidade de tratamento com TFD para este tipo de tumor. 


\section{Evidências experimentais das alterações da resposta à TFD após múltiplas sessões}

Neste capítulo será realizada uma investigação detalhada sobre as alterações da resposta das células tumorais após múltiplas sessões da terapia fotodinâmica (TFD). Para simular este tipo de procedimento in vitro, foram realizadas sucessivas sessões da TFD em culturas de células de hepatocarcinoma. Entre as sessões de TFD, aguardou-se um intervalo de tempo suficiente para que as células sobreviventes se reproduzissem e formassem uma nova cultura celular. Para analisar a variação da morte celular em função da dose de luz entregue à cultura, foi realizado um experimento utilizando cinco frascos de cultura celular empilhados, simulando as camadas de um tecido, e dispostas em diferentes distâncias da fonte de luz, como mostra a Figura 9. Os resultados dos experimentos serão úteis na discussão do modelo teórico proposto e de suas implicações.

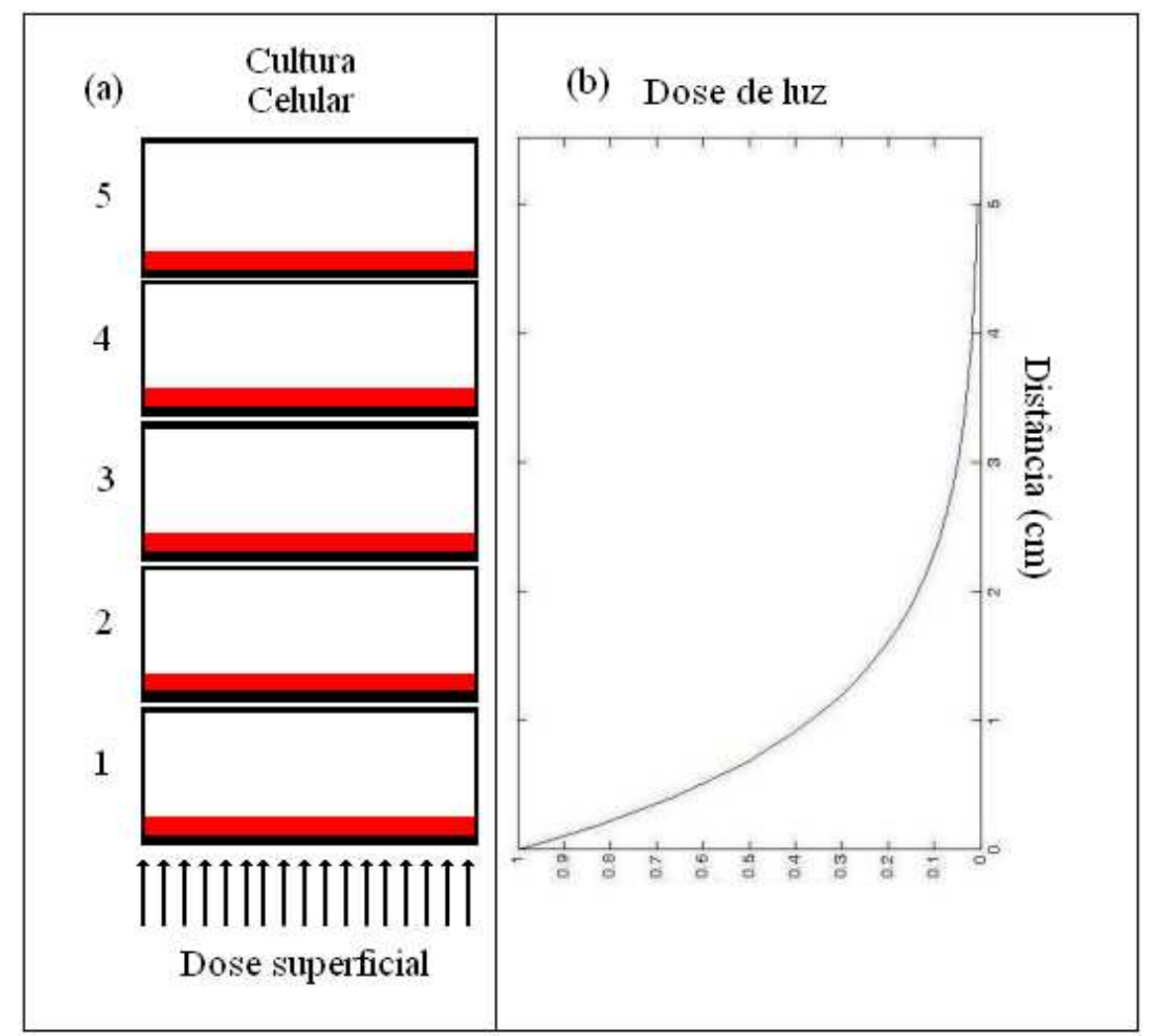

Figura 9 - (a) Ilustração da disposição dos frascos contendo as culturas celulares utilizada no experimento com TFD. (b) Representação gráfica da distribuição de luz em função da distância à superfície. 


\subsection{Descrição do experimento}

\subsubsection{Fotossensibilizador}

O fotossensibilizador (FS) utilizado nos experimentos foi o Photogem ${ }^{\circledR}$ (Academia de Alta Tecnologia de Química de Moscou, Rússia). Foram preparadas soluções estoque de $5,0 \mathrm{mg} / \mathrm{ml}$ do Photogem em solução salina tamponada com fosfato ( $\mathrm{pH}$ de 7.4) e estocadas em refrigerador a $4^{\circ} \mathrm{C}$. A escolha deste FS, um derivado de hematoporfirina, está diretamente relacionada às suas propriedades para TFD; entre elas, destacamos o perfil de absorção de luz, apresentado no gráfico da Figura 10. Este espectro revela a forte absorção de luz pelo Photogem na região espectral do ultravioleta (Banda de Soret, 300-380nm) com um pico de absorção entre 330 e 340nm (Figura 10, lado esquerdo). Além dessa, há uma absorção mais fraca na região espectral do visível, mais caracterizados pelos picos em $470 \pm 5 \mathrm{~nm}, 500 \pm$ $5 \mathrm{~nm}, 550 \pm 5 \mathrm{~nm}$ e $630 \pm 5 \mathrm{~nm}$ (Bandas Q, Figura 10, lado direito). 


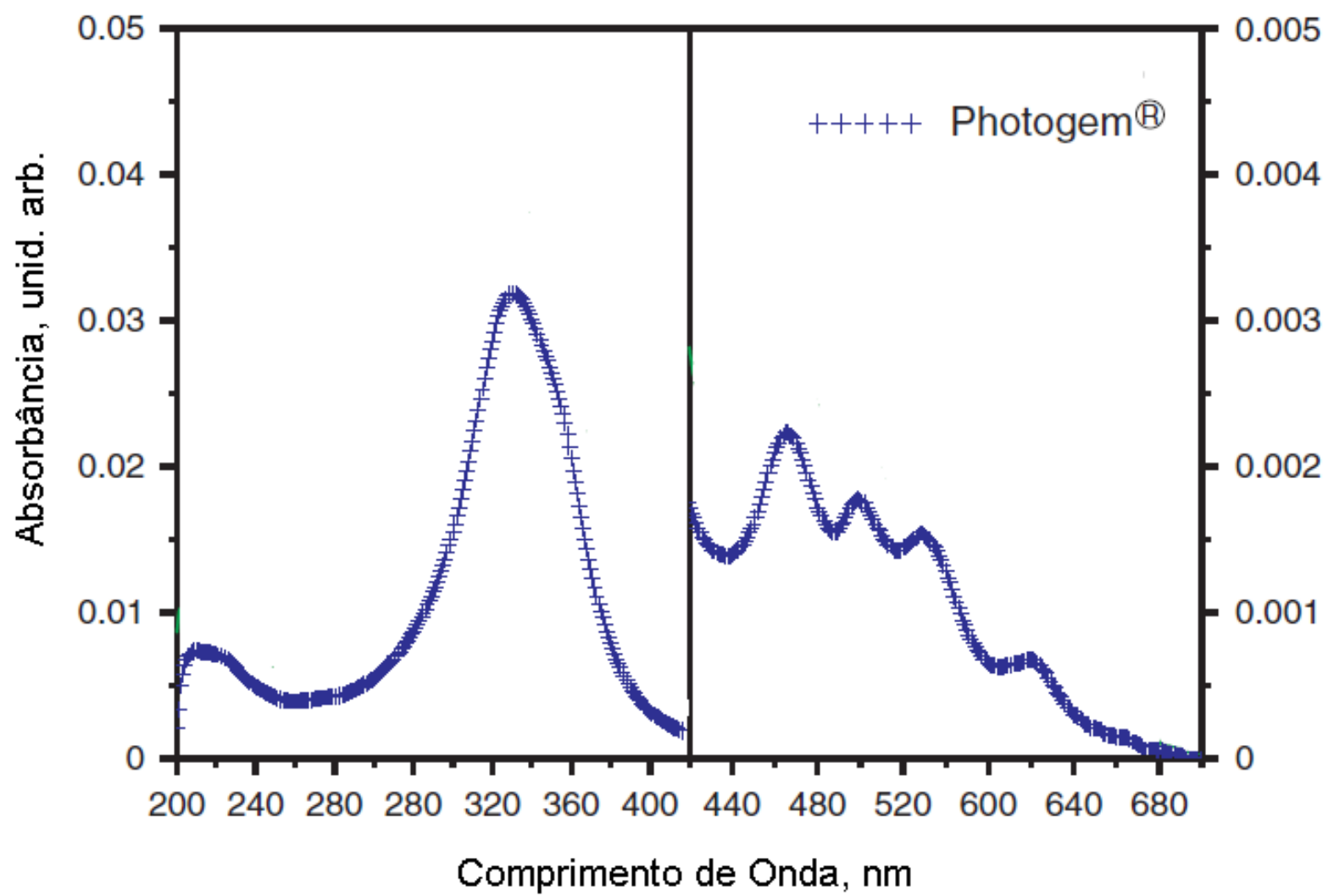

Figura 10 - Espectro de absorção do Photogem, revelando sua forte absorção de luz na região do ultravioleta (Banda de Soret, lado esquerdo do gráfico) e uma absorção mais fraca na região espectral do visível (Bandas Q, lado direito do gráfico) ${ }^{4}$.

A absorção de luz vermelha $(630 \pm 5 \mathrm{~nm})$ é a principal característica explorada com esse fotossensibilizador, pois a literatura científica revela que fótons de maiores comprimentos de onda possuem um maior poder de penetração nos tecidos biológicos do que fótons com comprimentos de onda mais curtos, de forma que o efeito fotodinâmico utilizando-se luz e $630 \mathrm{~nm}$ pode ser ativado em regiões mais profundas dos tecidos ${ }^{1,10}$. Entretanto, deve-se destacar que a intensidade de luz vermelha necessária para ativar o efeito fotodinâmico deve ser maior que a intensidade para o ultravioleta, devido à menor eficiência na absorção pelo FS. O Photogem é um dos poucos agentes fotossensibilizantes aprovados no Brasil pela Agência Nacional de Vigilância Sanitária (ANVISA) para o tratamento do câncer de pele. $\mathrm{O}$ medicamento mais semelhante a ele, de mais larga utilização, porém de maior custo, é o Photofrin ${ }^{\circledR}$ (porfimer sodium - QLT Inc, Vancouver, Canadá), aprovado pelo FDA (Food and Drug Administration - EUA) para uso no tratamento de câncer de pele, esôfago, entre outros. Estes FS são muito estudados em experimentos de TFD com modelos animais ${ }^{8}$. 


\subsubsection{Linhagem celular}

Neste experimento, foram utilizadas linhagens celulares de hepatocarcinoma (HepG2), as quais foram fornecidas pelo Prof. Dr. Luis Fernando Tirapelli do Departamento de Cirurgia e Anatomia da Faculdade de Medicina de Ribeirão Preto da Universidade de São Paulo (FMRP-USP), e que são comercializadas por meio da American Type Culture Collection (ATCC-Rockville, Maryland, , EUA). Esta linhagem celular é usada em testes de várias drogas anti-câncer, além da radioterapia. Muitos trabalhos do nosso grupo utilizam o fígado de rato como modelo animal (devido a uma maior homogeneidade óptica com relação a outros tecidos), portanto, os parâmetros utilizados nesses experimentos poderão ser utilizados para fins comparativos.

\subsubsection{Cultivo celular}

As linhagens celulares foram estocadas em nitrogênio líquido (a $-195{ }^{\circ} \mathrm{C}$ ) em alíquotas de $1 \times 10^{5}$ células/ml, em uma solução de congelamento contendo $50 \%$ de meio de cultura celular, $40 \%$ de soro fetal bovino (Cultilab®, Campinas, Brasil) e 10\% de dimetilsulfóxido (DMSO). O meio de cultura adotado é uma modificação do Meio Basal Eagle (BME) que contém quatro vezes a concentração de aminoácidos e vitaminas e é denominado Dulbecco's Modified Eagle's Medium (DMEM, GIBCO® invitrogen). Está técnica de estocagem é chamada de criopreservação ${ }^{6}$.

Para a realização dos experimentos, as células foram descongeladas e cultivadas em monocamadas, dentro de frascos de cultura celular com área superficial de $25 \mathrm{~cm}^{2}$ (Techno Plastic Products, TPP, Trasadingen, Suíça). Cada solução para cultura celular continha 5,0 ml de DMEM suplementado com $10 \%$ de soro fetal bovino, e foi incubada em estufa a $37{ }^{\circ} \mathrm{C}$ e 5 
$\%$ de $\mathrm{CO}_{2}$, até atingirem a população de $5 \times 10^{5}$ células. $\mathrm{O}$ subcultivo das células foi realizado através da tripsinização ${ }^{6}$ com o objetivo de desprender as células da placa. Este processo consiste em adicionar meio de cultura e tripsina nos frascos com as células e em seguida leválos para uma estufa na qual as células serão incubadas a $37^{\circ} \mathrm{C}$ durante 5 minutos - período necessário para o rompimento das ligações entre as células. Após esse período, o desprendimento das células pode ser observado ao microscópio.

Em seguida, o meio de cultura juntamente com a tripsina foi removido, e apenas o meio de cultura foi adicionado às células. No passo seguinte, as culturas foram centrifugadas a 1200 RPM durante 7 minutos a $23{ }^{\circ} \mathrm{C}$. Por fim, o sobrenadante foi descartado, uma lavagem com 1,0 ml de tampão fosfato-salino (PBS) foi realizada e as células foram re-suspensas em $1,0 \mathrm{ml}$ de meio de cultura, em novos frascos.

\subsubsection{Contagem das células}

Para a determinação da viabilidade celular utilizou-se o método tradicional de contagem em câmara de Newbauer. Neste método, o corante azul de Tripan (C34H28N6O14S4) é adicionado ao tecido e se aloja, seletivamente, nas células mortas, em conseqüência dos danos causados às suas membranas celulares. Para a contagem celular, foram colocados $50,0 \mu \mathrm{L}$ de células re-suspensas juntamente com 50,0 $\mu \mathrm{L}$ de azul de Tripan em um microtubo tipo "Eppendorf" de 2,0 ml. Após a homogeneização da solução, foram adicionados $20 \mu \mathrm{L}$ da solução de células contendo azul de Tripan na câmara de Newbauer. Contou-se o número de células, multiplicando-se o valor encontrado por dois (fator de diluição) e por $10^{4}$ (fator de correção da câmara de Newbauer), obtendo-se a concentração de células por mililitro de suspensão ${ }^{6}$.

A determinação da fração de morte celular foi realizada através do cálculo da razão entre o número de células vivas e o número de células mortas. Neste tipo de coloração, as células vivas são incolores vistas ao microscópio, enquanto as células mortas apresentam 
coloração violeta devido à incorporação do azul de Tripan. O cálculo da fração de morte celular foi realizado através da fórmula:

$$
f(\%)=100 \times\left(\frac{n}{N}\right)
$$

onde $f$ é a fração de morte celular (em porcentagem), $n$ é o número de células coradas e $N$ é o número total de células ${ }^{66}$.

\subsubsection{Fonte de luz}

\subsubsection{1 "BioTable”}

Durante os experimentos para realizar a irradiação das células e, conseqüentemente, ativar o efeito fotodinâmico nas amostras preparadas, utilizou-se um equipamento composto por diodos emissores de luz (light-emitting diodes, LEDs) de alto brilho, de nome "BioTable". A BioTable foi desenvolvida no Laboratório de Apoio Tecnológico do Instituto de Física de São Carlos e utiliza uma matriz de 24 diodos (6 x 4) emissores na banda espectral de $630 \pm 10$ nm (luz vermelha). Na montagem, a matriz de diodos fica posicionada a uma distância previamente estabelecida da superfície externa do equipamento. É essa distância que propicia a irradiação na superfície mais uniforme e mais intensa possível.

O revestimento externo da BioTable é formado por um corpo metálico, um dissipador térmico e uma fonte elétrica. O corpo metálico tem a função de alinhar opticamente a matriz de diodos à superfície do equipamento, além de concentrar a luz emitida na mesma superfície. O dissipador térmico tem a função de estabilizar a temperatura de operação dos 
diodos de alta potência uma vez que, a altas temperaturas de operação, o processo de falência ("queima") dos diodos ocorre precocemente. Este dissipador térmico deve ser robusto e efetivo; para isso, foi acoplada uma estrutura de metal associada com ventiladores tipo cooler (ventoinhas).

O uso da BioTable para irradiação de amostras de cultura celular envolve o posicionamento do recipiente na superfície do equipamento; contudo, como discutido nas sessões anteriores, diferentes intensidades de irradiação promovem efeito fotodinâmico mais ou menos intenso. Por isso, tal equipamento foi projetado para prover quatro níveis de intensidade de irradiação, baseados na corrente de operação dos diodos. A Figura 11 apresenta a BioTable e destaca seus principais componentes.

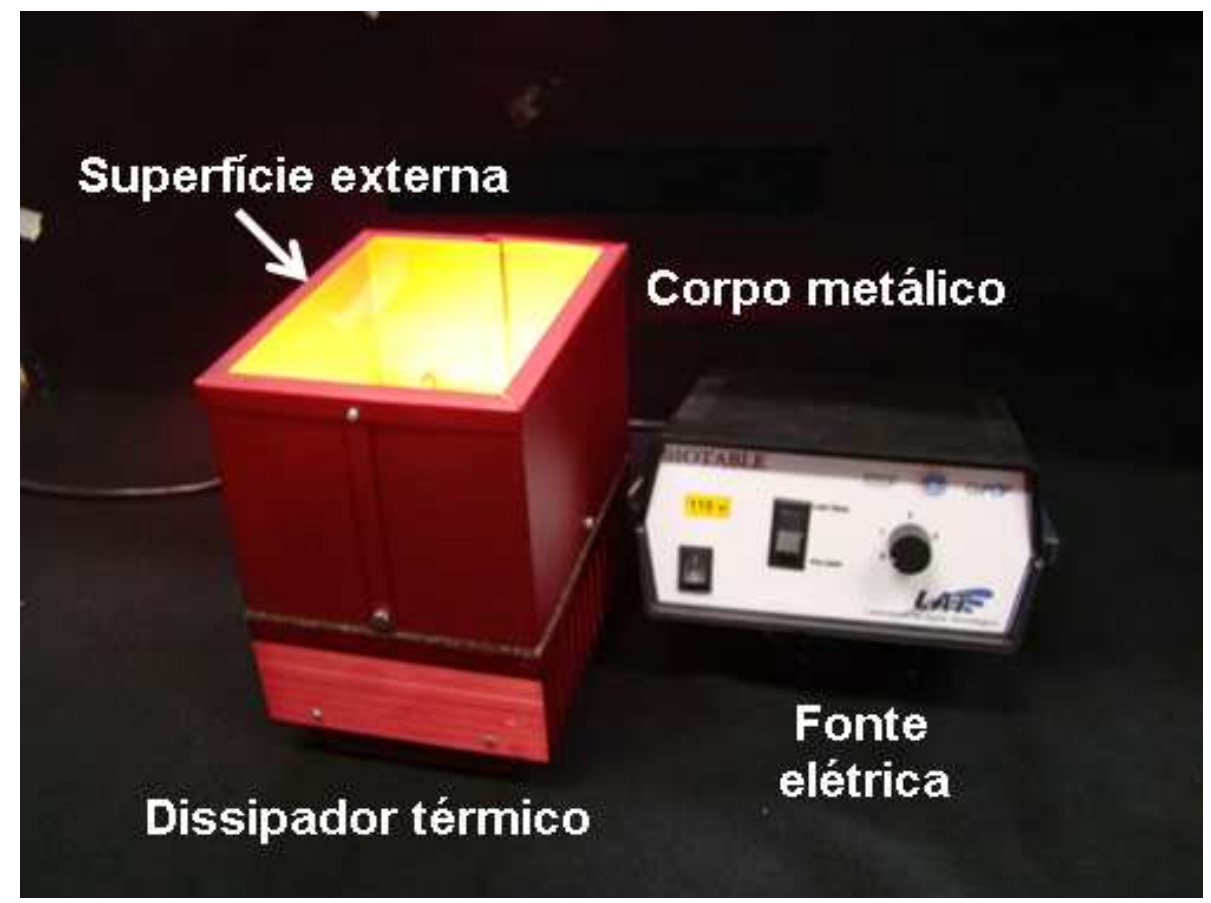

Figura 11 - Equipamento Biotable utilizado para a iluminação das culturas celulares. Ele é composto por uma matriz de 24 diodos emissores de luz com alto brilho numa banda espectral centrada em $630 \mathrm{~nm}$, um corpo metálico para alinhamento óptico e confinamento da luz, um dissipador térmico para manter estável a temperatura dos diodos e uma fonte de energia que provê a tensão e a corrente de operação do equipamento. 


\subsubsection{Caracterização da BioTable}

As medidas da intensidade de emissão da Biotable foram realizadas apenas para o nível "4" de emissão, a maior intensidade obtida pelo equipamento. Esta intensidade foi utilizada em todos os experimentos com culturas celulares. Na caracterização, a intensidade de luz emitida pela Biotable foi medida utilizando um dispositivo composto por oito fotodetectores do tipo BPW-34, dispostos em uma placa para cultura de células com 24 poços, como mostra a Figura 12. Tal dispositivo também foi desenvolvido no Laboratório de Apoio Tecnológico do Instituto de Física de São Carlos.

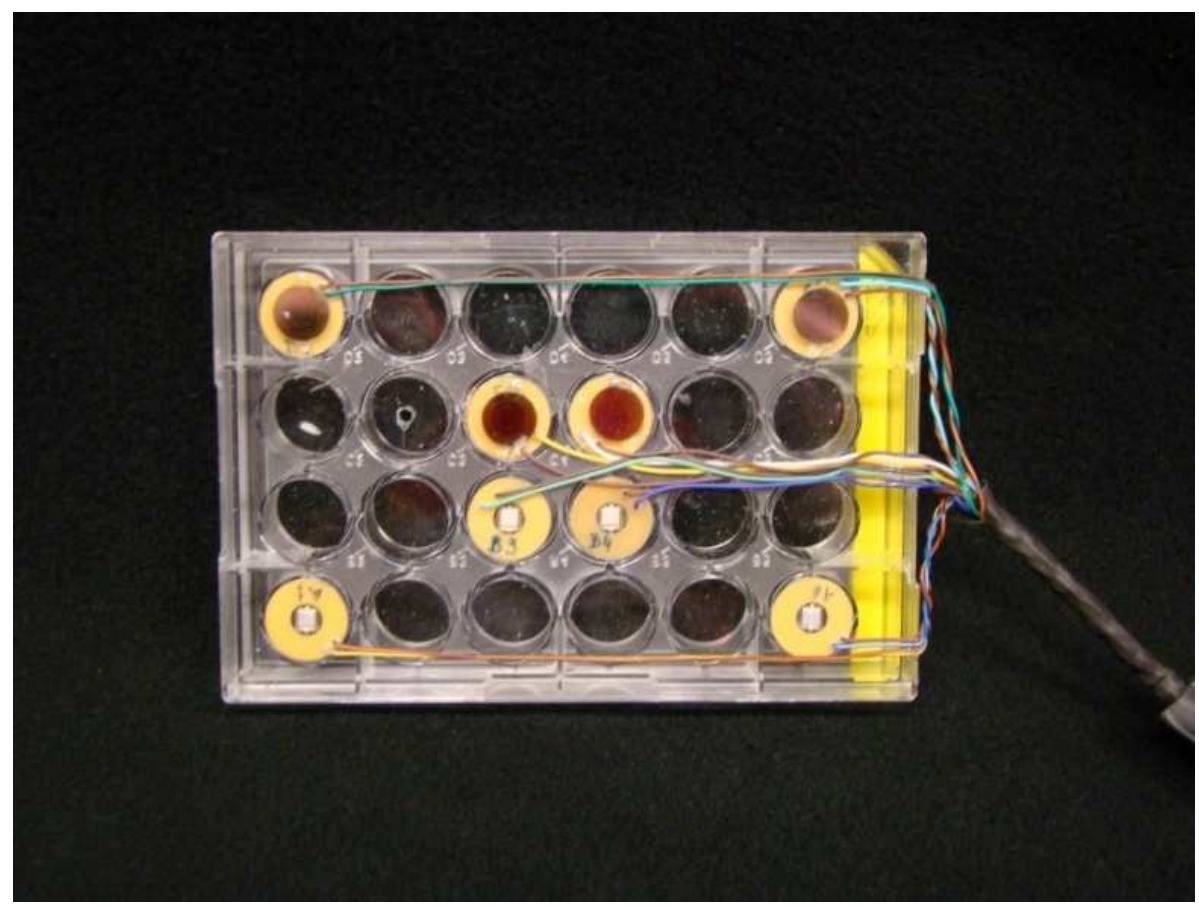

Figura 12 - Dispositivo de medida da intensidade óptica emitida pela Biotable, o qual é composto por oito fotodetectores (BPW-34) acoplados a uma placa de cultura celular.

Os fotodetectores estão ligados a um circuito eletrônico, conectado por sua vez a um sistema de aquisição de dados analógicos e digitais NI 9215 (National Instruments, Austin, EUA); esta placa de aquisição é a interface entre o circuito eletrônico e o computador. Uma 
rotina computacional desenvolvida no programa LabVIEW (National Instruments, Austin, EUA) captura os dados e calcula médias da intensidade de luz medida por cada fotodetector. A medida do dispositivo citado foi calibrada por um medidor de potência óptica FieldMaster (Coherent Inc., San Jose, EUA), permitindo que o valor de intensidade medido com os fotodetectores pudesse ser convertido em $\mathrm{mW} / \mathrm{cm}^{2}$.

A intensidade da luz emitida pela BioTable foi medida no centro e nas extremidades da placa de cultura celular com a intenção de verificar a homogeneidade da irradiação sobre toda a área da superfície externa do equipamento. É importante destacar que a área da placa de 24 poços é aproximadamente igual à área da superfície externa da BioTable, de forma que a medida da placa representa a medição no equipamento. Com os valores medidos pelos oito sensores foi determinada a intensidade média de iluminação na superfície da BioTable.

Para o experimento proposto, é interessante conhecer a intensidade de luz que atinge a placa de cultura celular não só na superfície, mas também dentro de cada recipiente empilhado; de forma a conhecer a quantidade de luz que atinge cada camada celular do modelo experimental. Para realizar essa medida, o dispositivo com os fotodetectores foi utilizado sobre os recipientes, alternando a sua posição ao longo dos cinco frascos. $\mathrm{O}$ procedimento experimental pode ser visto na Figura 13. Ela mostra o dispositivo com fotodetectores sobre dois frascos de cultura celular, efetuando a medida na terceira camada de células. Devido ao posicionamento dos fotodetectores nas extremidades e no centro do dispositivo, e ao tamanho do frasco de cultura celular ser menor que a placa de 24 poços, apenas a região central do dispositivo (quatro fotodetectores no centro da placa) foi utilizada para as aferições. 


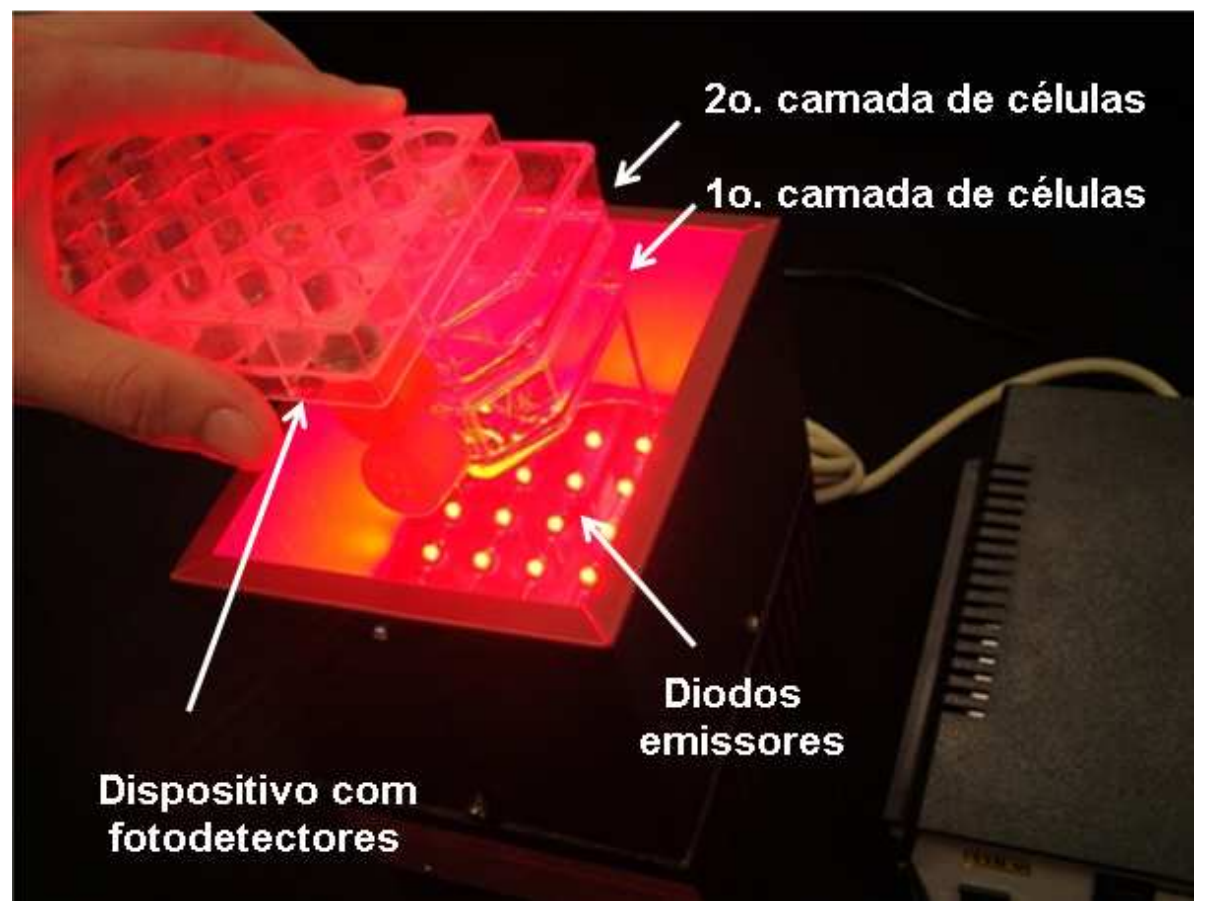

Figura 13 - Imagem obtida durante a dosimetria da BioTable calibrando a terceira camada de células do experimento. Aqui apenas um dos fotodetectores ligados na placa de 24 poços está realizando a medida. Entre a superfície da BioTable e o fotodetector estão dois frascos (primeira e segunda camada de células) contendo meio de cultura DMEM.

Os valores de intensidade foram medidos para o nível máximo de operação da BioTable. A partir dos resultados, é possível gerar uma curva que revele o perfil de decréscimo da intensidade de iluminação em função da distância. Esse perfil pode ser visto na Figura 14, através de um gráfico que apresenta a intensidade de iluminação $\left(\mathrm{em} \mathrm{mW} / \mathrm{cm}^{2}\right) \mathrm{em}$ função da distância (em cm) à superfície da Biotable; neste gráfico, a distância igual a zero representa a intensidade na superfície. 


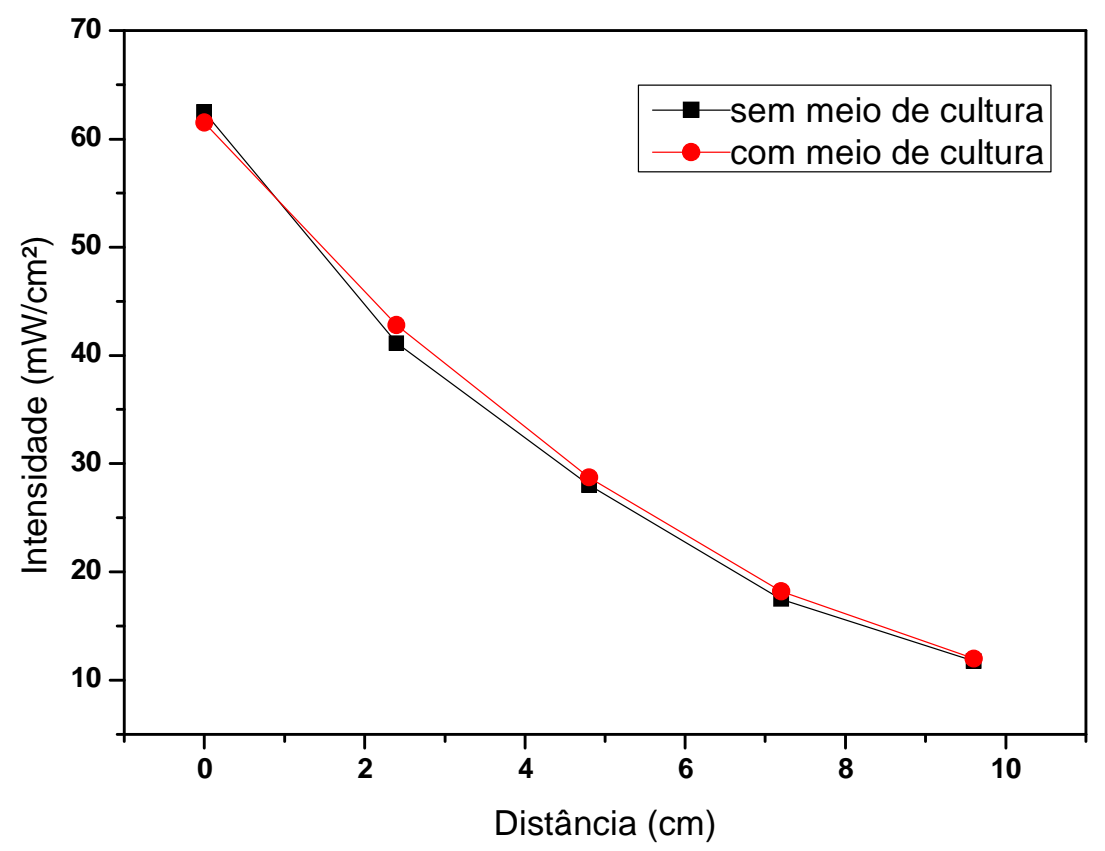

Figura 14 - Resultado das aferições realizadas com os frascos empilhados. Os círculos representam o perfil de distribuição de luz em função da distância entre a superfície da BioTable e os frascos contendo meio de cultura. Os quadrados representam a intensidade para os frascos apenas.

A partir dos dados de caracterização da BioTable, escolheu-se aplicar a máxima intensidade de iluminação sobre as camadas de células $\left(4^{\circ}\right.$ nível de operação do equipamento); a média das aferições de intensidade foi de $60 \pm 5 \mathrm{~mW} / \mathrm{cm}^{2}$. Com a informação da intensidade de irradiação $(I)$, foi possível calcular a densidade de energia (ou dose de luz) entregue pelo equipamento às camadas de culturas celulares, bastando escolher o tempo total de irradiação $\left(T_{i r r}\right)$. A dose $(D)$ é calculada de acordo com a Equação 4.2, e verifica-se que, para uma intensidade de $60 \pm 5 \mathrm{~mW} / \mathrm{cm}^{2}$ (aplicada na primeira cultura celular) e um tempo total de irradiação de 900 segundos, seu valor será de $54 \pm 4 \mathrm{~J} / \mathrm{cm}^{2}$.

$$
D=I . T_{i r r}
$$

As doses de luz entregues às culturas celulares durante os experimentos in vitro são mostradas no gráfico da Figura 15. Foi realizado um ajuste linear da curva de decréscimo da dose de luz e em seguida estimado o valor de $\mu=0,137$ nessas condições do experimento. 


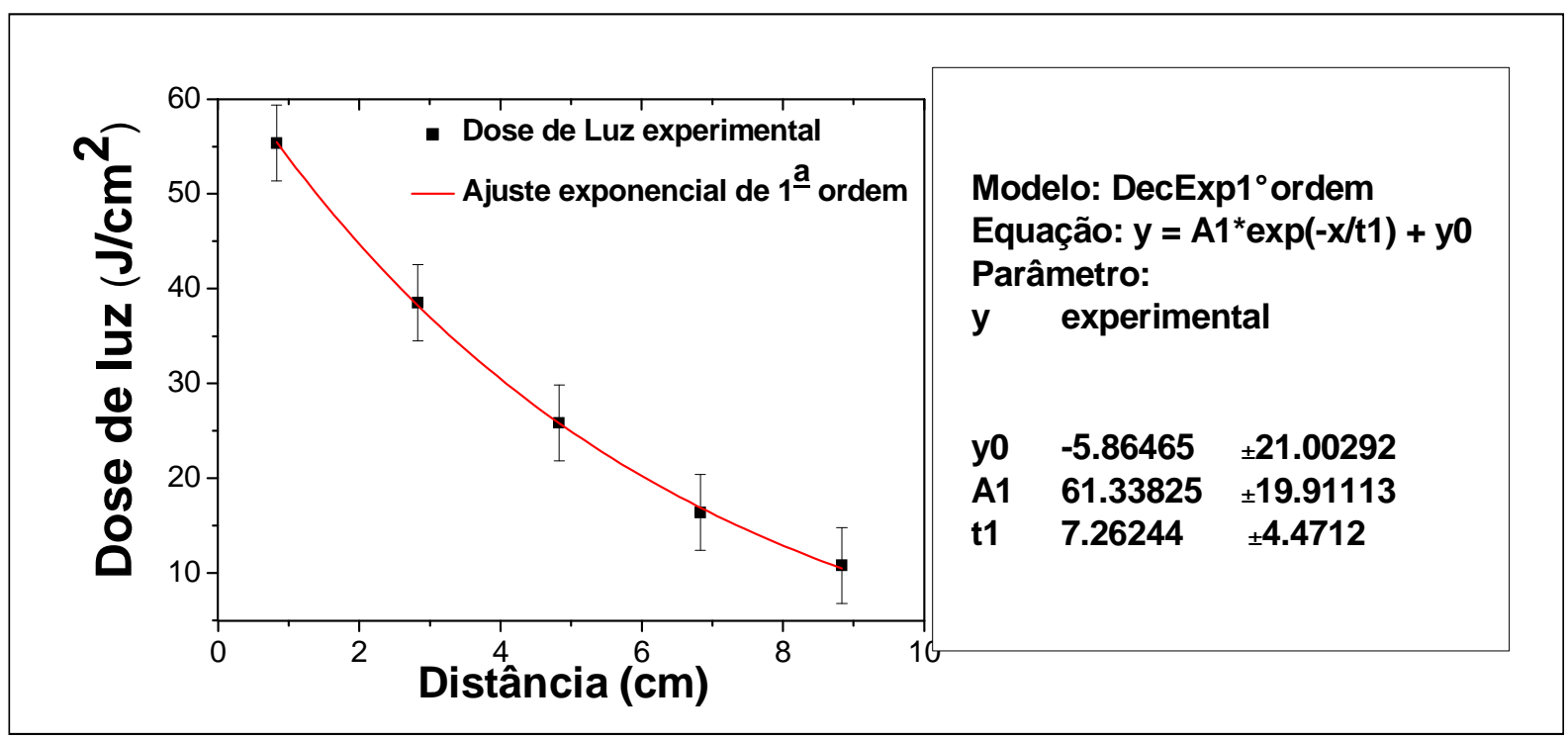

Figura 15 - Dose de luz $\left(\mathrm{em} \mathrm{J} / \mathrm{cm}^{2}\right)$ entregue às culturas celulares empilhadas durante os experimentos com TFD in vitro, com relação à distância $(\mathrm{em} \mathrm{cm})$ da cultura celular à superfície da BioTable.

\subsection{Resultados experimentais}

\subsubsection{Terapia fotodinâmica in vitro}

As culturas celulares continham entre 70 mil e 90 mil células/ml. É importante salientar que o tempo de absorção do fotossensibilizador (FS) pelas células nos seres humanos é de pouco mais que 24 horas; no entanto, para células em cultura é necessário aguardar um período de 4 horas para irradiá-las. As culturas foram empilhadas, simulando camadas celulares sobrepostas, ou seja, que estariam a diferentes distâncias da fonte de luz. O comprimento de onda da radiação emitida pela BioTable $(630 \mathrm{~nm})$ foi escolhido devido ao pico de absorção do Photogem estar nesta mesma região espectral e se adequar às condições da janela biológica, motivo pelo qual o mesmo comprimento de onda é utilizado em pacientes na clínica. 
As linhagens celulares foram incubadas com o FS na concentração de 5,0 $\mu \mathrm{g} / \mathrm{ml}$, durante 4 horas após a substituição do meio de cultura. Em seguida, as culturas foram iluminadas usando o arranjo experimental mostrado na Figura 16. Depois de 24 horas do término da iluminação, as culturas celulares foram devidamente processadas e em seguida foram realizadas as contagens das células vivas e mortas. Desta forma, pode-se aferir a variação da fração de morte para cada uma das culturas celulares empilhadas em função da distância.

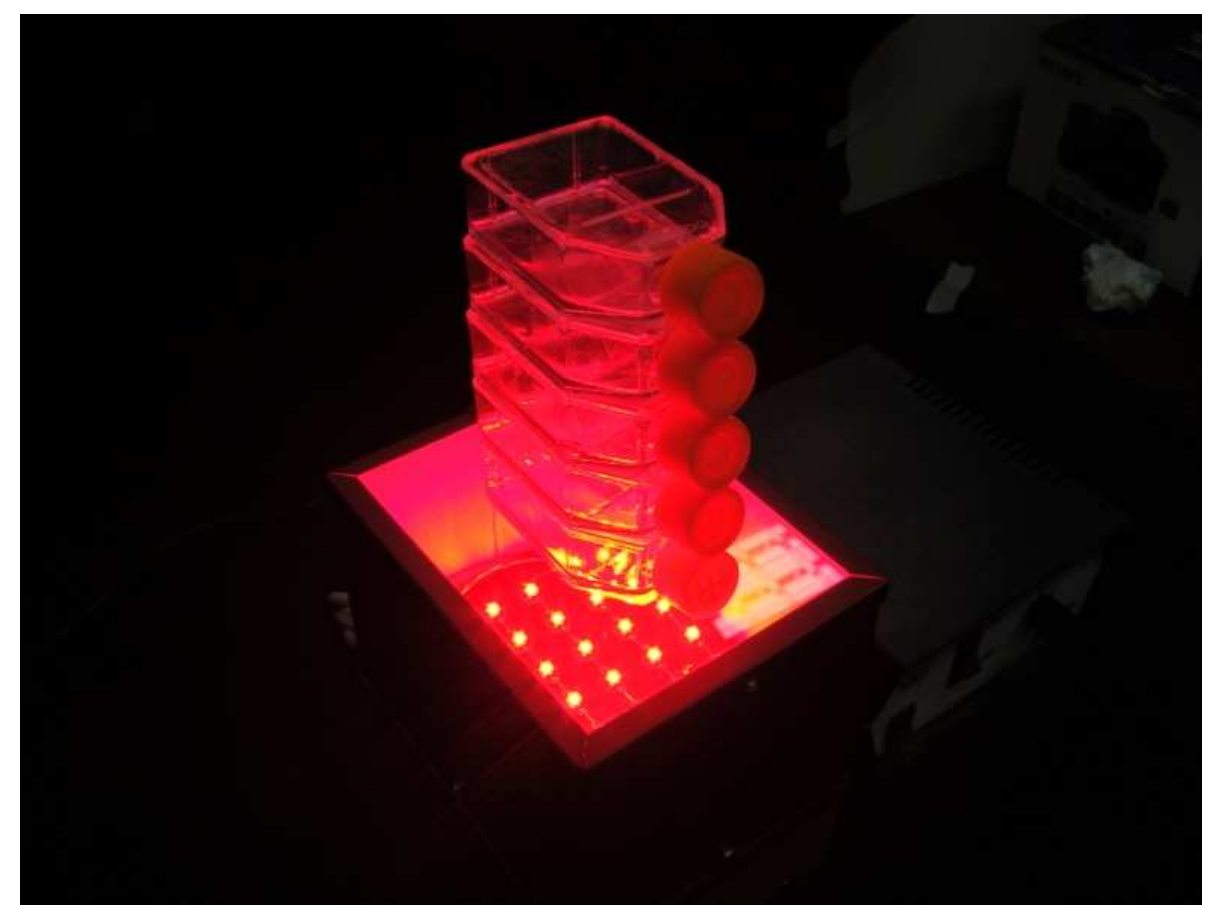

Figura 16 - Imagem ilustrativa da disposição dos frascos de cultura celular empilhados para simular várias camadas de um tecido em diferentes profundidades, recebendo iluminação durante a sessão da TFD.

Para os experimentos com os frascos empilhados foram criados três grupos de culturas celulares. O Grupo 1 foi submetido a 5 sessões da TFD; no Grupo 2 as células foram somente iluminadas (sem FS) e no Grupo 3 as culturas de células continham apenas FS mas não foram iluminadas. Foram realizadas 5 sessões sucessivas da TFD com os frascos empilhados. Após cada sessão, foi aguardado um intervalo de tempo de 24 horas, após o qual as culturas celulares foram contadas e a fração de morte das células aferida. A dose de luz na superfície da Biotable foi de $54 \pm 4 \mathrm{~J} / \mathrm{cm}^{2}$ em todas as sessões da TFD. O resultado deste experimento está representado no gráfico da Figura 17. 


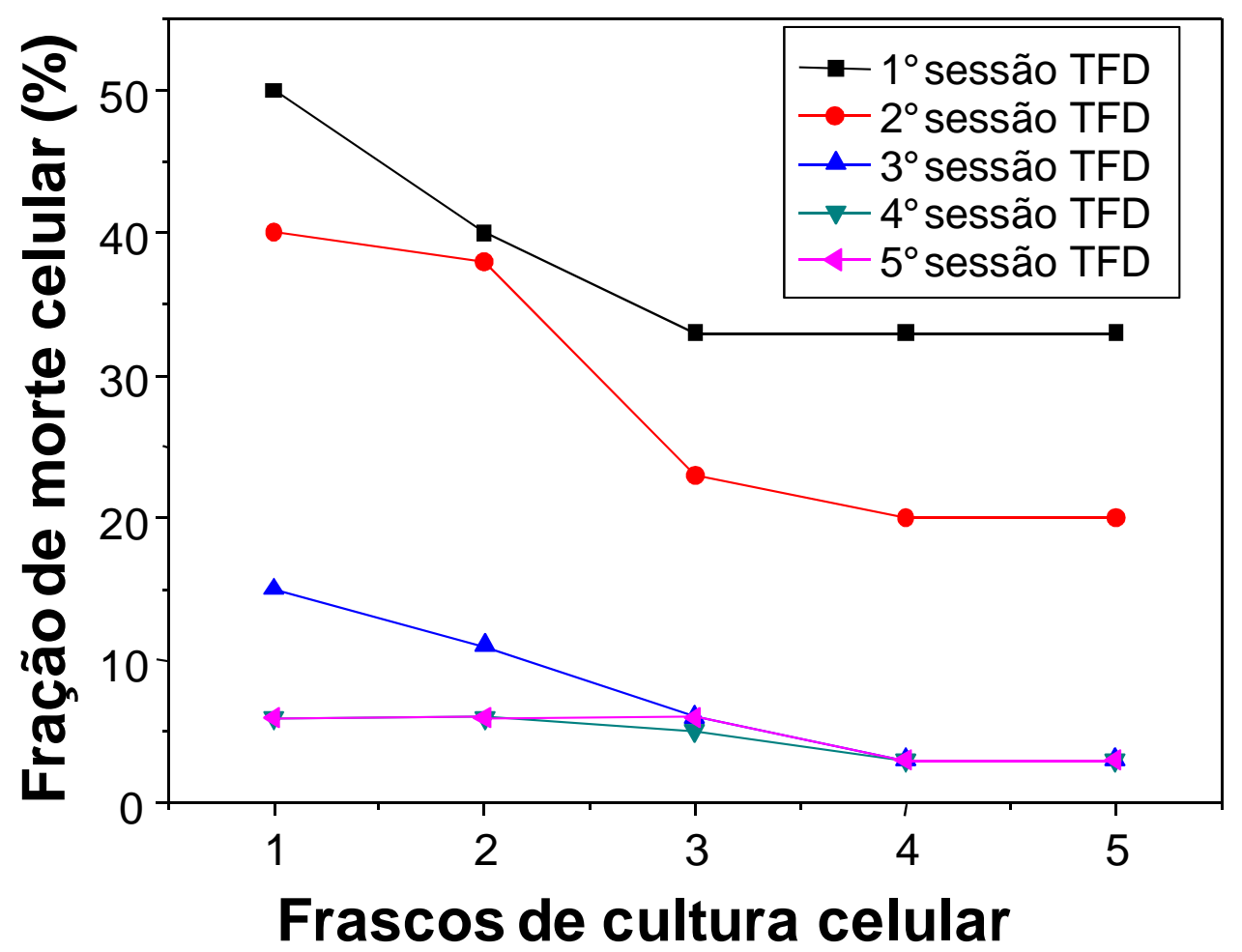

Figura 17 - Fração de morte (\%) após sucessivas sessões da TFD em função da distância da cultura celular à superfície da BioTable. Utilizou-se a linhagem HepG2, e cada cultura submetida a TFD foi cultivada novamente após a iluminação e contagem das células. A cultura celular originada das células sobreviventes a $1^{\circ}$ sessão da TFD foi submetida à $2^{\circ}$ sessão e assim sucessivamente, até a $5^{\circ}$ geração de células.

Na Figura 17 observa-se que a fração de morte diminuiu a cada sessão da TFD. Esta diminuição foi prevista pelo modelo teórico de distribuição de $D_{t h}$. Tal redução pode ser uma evidência da diminuição da ação fotodinâmica ou do aumento da resistência da cultura celular à terapia. $\mathrm{Na}$ cultura celular do frasco 1 (mais próxima da BioTable, considerada como a superfície do modelo experimental) a primeira sessão da TFD causou uma fração de morte de $50 \%$, o que significa que a dose de luz entregue pela BioTable no frasco 1 , de $54 \pm 4 \mathrm{~J} / \mathrm{cm}^{2}$, está próxima do valor médio da $\overline{D_{t h}}$ desta cultura celular para estas condições.

No modelo teórico, assumimos que a população celular do tumor original apresentava a mesma largura $\left(\sigma_{0}\right)$ da distribuição de dose limiar em função da profundidade. A estimativa 
do valor de $\sigma_{0}$ pode ser realizada de acordo com a Equação (3.14), utilizando-se a aproximação da $\overline{D_{t h}}$, resultando em aproximadamente $48 \mathrm{~J} / \mathrm{cm}^{2}$. A simulação da fração de morte de acordo com o modelo teórico proposto, a dose superficial usada nos experimentos (aproximadamente $54 \mathrm{~J} / \mathrm{cm}^{2}$ ), e o coeficiente de atenuação obtido na caracterização da BioTable $(\mu=0,137)$, é representada na Figura 18, pela curva de linha contínua.

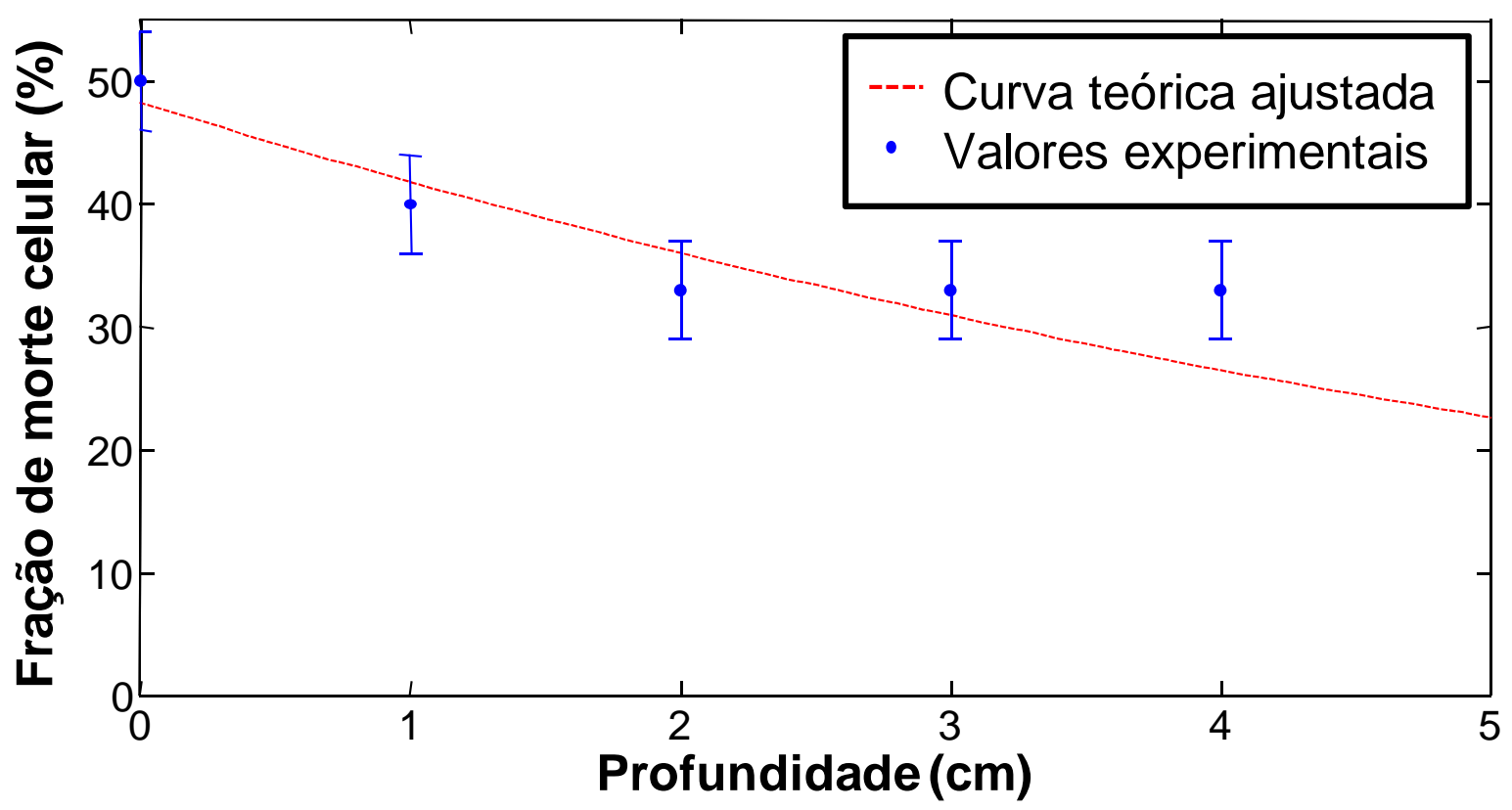

Figura 18 - Linha contínua: Fração de morte obtida da simulação da primeira sessão da TFD de acordo com o modelo, utilizando o valor da largura da Gaussiana de $120 \mathrm{~J} / \mathrm{cm}^{2}$. Círculos: Curva de fração de morte celular obtida após a primeira sessão da TFD nos experimentos in vitro. Linha tracejada: Curva de fração de morte celular obtida da simulação da primeira sessão da TFD de acordo com o modelo teórico, utilizando um valor da largura da Gaussiana ajustado.

A Figura 18 mostra os valores experimentais da fração de morte para a primeira sessão da TFD (círculos). Nota-se que a simulação (linha contínua) gerada pelo modelo se aproxima da curva experimental (círculos). O modelo considera que a luz se propaga num tecido contínuo, diferente da disposição das culturas celulares utilizadas no experimento in vitro, porém as medidas da dose de luz demonstraram concordância com o modelo de distribuição de luz teórico. Considerando uma variação na penetração da luz (e, portanto, diminuição de $\mu$ ), pode-se considerar que morrerão mais células em profundidades maiores, aumentando o $\sigma_{0}$ da distribuição de dose limiar; ou seja, existe uma relação entre o coeficiente de atenuação e a largura da distribuição de dose limiar. Uma vez que os ajustes mostram uma melhoria do modelo com relação ao experimento, podemos considerar que o modelo reflete razoavelmente 
o que acontece nas culturas de células, e, portanto pode ser melhorado para representar fielmente a realidade.

Ao analisar os resultados experimentais, observa-se que a fração de morte diminui à medida que a distancia entre a cultura celular e a superfície da BioTable aumenta. Mostrando que a fração de morte celular está diretamente ligada à dose de luz entregue às culturas celulares. À medida que a dose de luz diminui a fração de células mortas também diminui. No entanto, a simulação teórica da segunda sessão da TFD com dose de luz $D_{0}=1 \sigma_{0}$ promove um padrão de morte muito diferente daquele observado na segunda sessão da TFD experimental em culturas de células. Esta divergência entre a resposta simulada e a observada no experimento sugere que a distribuição de dose limiar proposta deve ser ajustada para as condições de cada alvo, neste caso trata-se de células em cultura. É importante lembrar que tal divergência também pode ser resultado de alterações na propagação da luz que porventura tenham sido ignorados, como o espalhamento causado pelas camadas de ar entre as culturas de células.

A redução do efeito fotodinâmico fica clara, inclusive em culturas celulares mais distantes da BioTable. Na terceira sessão da TFD in vitro, a fração de morte é de apenas $15 \%$, ou seja, a eficácia da ação fotodinâmica sofreu uma redução; pode-se observar também que nos frascos 4 e 5 (mais distantes da superfície da BioTable), a fração de morte foi inferior a $5 \%$, valor semelhante a fração de morte dos grupos controle, onde não houve ação fotodinâmica. Nessas condições, provavelmente não foi alcançada a $D_{t h}$. Isto significa que não houve dano irreversível às células das culturas 4 e 5 após a terceira sessão da terapia.

Estes resultados sugerem que a ação fotodinâmica perde seu potencial de destruição das culturas celulares após 3 sessões utilizando dose de luz de $54 \pm 4 \mathrm{~J} / \mathrm{cm}^{2}$, para a linhagem HepG2 in vitro. Não se podem afirmar quais os mecanismos fizeram com que as células das culturas de $3^{\circ}, 4^{\circ}$ e $5^{\circ}$ gerações adquirissem resistência à TFD, no entanto a diminuição da fração de morte após várias sessões da TFD é uma evidência considerável do aumento da $\overline{D_{t h}}$. A fração de morte para os grupos controle não ultrapassou 5\%, e é atribuída à própria mortalidade das células no meio, nestas condições de cultivo celular. Esta fração de morte indica que nem a toxicidade no escuro do FS, nem a luz por si só foram relevantes na morte das células, reforçando o fato de que a fração de morte celular observada no Grupo 1 é resultado da ação fotodinâmica. 
Estes resultados reforçam a possibilidade da existência de uma distribuição de dose limiar em um tecido neoplásico. Entretanto, as simulações previram um grande aumento na resistência entre a primeira e a segunda sessão da TFD, representado pelo aumento de $\sigma_{0}$. Contudo, o aumento da resistência celular à TFD observado nos experimentos in vitro foi menos expressivo. 


\section{Conseqüências clínicas da distribuição larga de $D_{t h}$}

O modelo de distribuição larga de $D_{t h}$ apresentado nesse estudo representa um avanço significante no entendimento da resposta tumoral à TFD para casos em que o tumor está em estágio avançado e apresenta uma população de células de baixo grau de diferenciação. Na maioria dos casos avançados, a lesão neoplásica não é eliminada totalmente, causando a recorrência tumoral, sendo necessárias mais sessões da TFD para erradicação ou controle do tumor. A recorrência tumoral é um sério problema para os pacientes, porque tumores recorrentes são freqüentemente mais malignos que tumores primários $^{30}$. Entretanto, as conseqüências das sucessivas aplicações da TFD em termos da resistência tumoral à terapia não são conhecidas; o que se observa na clínica é a diminuição da ação fotodinâmica após a primeira sessão ${ }^{15}$. No modelo proposto, atribui-se a diminuição da ação fotodinâmica ao aumento da dose limiar média do tecido $\overline{D_{t h}}$ que é prevista pelo modelo teórico de distribuição de $D_{t h}$.

Segundo as simulações realizadas para uma distribuição larga de $D_{t h}$, a redução do efeito fotodinâmico no modelo de tumor ocorre após a primeira sessão. Isto significa que uma nova sessão de TFD com a mesma dose de luz não causará o dano desejado no tecido neoplásico. De acordo com o modelo, a primeira sessão da TFD causa um aumento mais acentuado nos valores de $D_{t h}$ na superfície, onde restaram apenas as células de mais alta resistência à TFD. À medida que a profundidade do tecido aumenta, a dose de luz entregue diminui, causando fração de morte cada vez menor. Portanto, em regiões mais profundas do tumor, sobrevivem as células de $D_{t h}$ intermediário, que após o recrescimento, formarão uma nova população de células de $D_{t h}$ mais baixo comparado com a superfície. Estas alterações da distribuição de $D_{t h}$ em função da profundidade do tecido criaram camadas de células mais resistentes ao efeito fotodinâmico na superfície do tecido tumoral.

A diminuição da fração de morte após a primeira sessão da TFD está relacionada com o aumento da $D_{t h}$ na superfície do tumor, embora os mecanismos que tornam estas células mais resistentes à TFD não sejam conhecidos. Nestas condições, uma nova sessão da TFD com a mesma dose de luz causará cada vez menos morte celular. Seria necessário, portanto, um aumento na intensidade e na dose de luz, para superar o $\overline{D_{t h}}$ das células nas 
proximidades da superfície. Esta tendência ao aumento da dose de luz pode trazer conseqüências ainda não exploradas neste estudo.

Na TFD, a dose de luz utilizada na clínica atualmente é calculada por uma simples relação entre intensidade de luz e tempo de exposição. Esta dosimetria é baseada na existência de um valor único de $D_{t h}$ para o tecido, fato que tem sido questionado neste estudo. A existência de uma distribuição larga de $D_{t h}$ levanta uma questão importante - qual deve ser a acurácia da dosimetria de luz no tratamento com várias sessões de TFD? Esta questão pode ser reescrita como: qual é a relação entre a resposta tumoral e a dose de luz entregue para tecidos normais e neoplásicos? Para responder estas perguntas, é necessário refinar o conceito de dose de luz em TFD, entender os princípios biofísicos da ação fotodinâmica e da resposta tumoral e, além disso, considerar a possibilidade da existência de uma variedade celular no tumor.

Os resultados dos experimentos in vitro, forneceram evidências da diminuição do efeito fotodinâmica em culturas celulares de HepG2 submetidas a sucessivas sessões da TFD. Neste experimento, não podemos afirmar que após a TFD as células sobreviventes se adaptaram e desenvolveram mecanismos que aumentaram sua resistência à TFD. Porém, supõe-se que a população da cultura celular de forma geral sofreu um aumento da dose limiar média $\overline{D_{t h}}$, definida anteriormente; desta forma, é possível supor que ocorreu uma seleção das células mais resistentes à ação fotodinâmica, a cada sessão, para a linhagem utilizada. Portanto, se esta seleção ocorre, pode-se atribuir à população de células tumorais, uma distribuição de $D_{t h}$ que represente a diversidade celular presente com razoável aproximação, ou seja, uma distribuição larga de $D_{t h}$.

A existência de células mais resistentes à TFD em uma mesma linhagem tem sido estudada por vários grupos. Casas e colaboradores realizaram experimentos utilizando a linhagem de adenocarcinoma mamário (LM3) para cultivo de 8 clones em cultura; nesse estudo, dois dos clones apresentaram maior resistência à TFD utilizando o ALA (amino levulinic acid, ácido aminolevulínico), um precursor da protoporfirina IX, uma porfirina endógena com ação fotodinâmica. A análise da morfologia dos clones resistentes mostrou que após a sessão da TFD, ocorreram modificações no citoesqueleto das células e em proteínas de adesão presentes nas membranas ${ }^{18,31}$. Estas alterações podem estar relacionadas com o aumento do $\overline{D_{t h}}$, embora mais estudos sejam necessários para que esta relação seja comprovada. 
A distribuição larga de dose limiar pode ter outras implicações no tratamento de tumores malignos. Sabe-se que esses tumores apresentam baixo grau de diferenciação, apresentando uma grande variedade de tipos celulares, incluindo células normais que foram recrutadas pela lesão neoplásica ${ }^{20}$. Se a sessão da TFD realmente causar um aumento da heterogeneidade celular no tumor, o estudo da distribuição de $D_{t h}$ pode representar uma nova ferramenta no combate ao câncer, não apenas em conjunto com a TFD, mas com outras técnicas, como a radioterapia, a cirurgia e a quimioterapia. 


\section{Conclusão}

Neste trabalho lançamos as bases de um novo conceito em terapia fotodinâmica. Trata-se da existência de uma distribuição de valores de dose limiar para células de um tecido neoplásico. O modelo criado mostra que em alguns casos pode ocorrer um aumento na resistência de tumores tratados com múltiplas sessões da TFD, o que de fato suporta a existência de uma distribuição de doses limiares. Um modelo experimental que representa camadas celulares foi desenvolvido para estimar os intervalos de valores de uma distribuição de doses limiares para células in vitro. O modelo poderá ser usado para diversos tipos de experimentos, inclusive em tecidos neoplásicos em modelos animais. Considerando as evidências da existência de uma distribuição de limiares, podem-se simular as consequiências de múltiplos tratamentos de um tumor. As observações indicam que, nos casos em que a lesão neoplásica não é erradicada pela TFD, ocorre um aumento da resistência da lesão à terapia, fazendo necessárias novas intervenções. Este trabalho, portanto, abre margem a novos estudos sobre a distribuição de dose limiar, os quais e poderão indicar o caminho para a eliminação total das lesões neoplásicas utilizando sucessivas sessões da TFD. 


\section{REFERÊNCIAS}

1 WILSON, B. C.; PATTERSON, M. S. The physics, biophysics and technology of photodynamic therapy. Physics in Medicine and Biology, v. 53, n. 9, p. 61-109, 2008.

2 DOUGHERTY, T. J.; GOMER, C. J.; HENDERSON, B. W.; JORI, G.; KESSEL, D.; KORBELIK, M.; MOAN, J.; PENG, Q. Photodynamic therapy. Journal of the National Cancer Institute, v. 90, n. 12, p. 889-905, 1998.

3 STEWART, F.; BAAS, P.; STAR, W. What does photodynamic therapy have to offer radiation oncologists (or their cancer patients)? Radiotherapy and Oncology, v. 48, n. 3, p. 233-248, 1998.

4 MENEZES, P. F. C. Estudos espectroscópicos e citotóxicos do Photogem fotodegradado e dos fotoprodutos formados pela irradiação com laser. 2006. $186 \mathrm{f}$. Tese (Doutorado), Instituto de Química de São Carlos, Universidade de São Paulo, São Carlos, 2006.

5 STRAUSS, W. S.; SAILER, R.; GSCHWEND, M. H.; EMMERT, H.; STEINER, R.; SCHNECKENBURGER, $H$. Selective examination of plasma membrane-associated photosensitizers using total internal reflection fluorescence spectroscopy: correlation between photobleaching and photodynamic efficacy of protoporphyrin IX. Photochemistry and Photobiology, v, 67, n. 3, p. 363-369, 1998.

6 CARVALHO, V. C. M. Estudo dos efeitos de duas porfirinas hidrofílicas em células tumorais Hep-2 visando aplicação em terapia fotodinâmica do câncer. 2001. $91 \mathrm{f}$. Dissertação (Mestrado em Química Analítica), Instituto de Química de São Carlos, Universidade de São Paulo, São Carlos, 2001.

7 FERREIRA, J.; MORIYAMA, L. T.; KURACHI, C.; SIBATA, C.; SILVA, O. C. E.; ZUCOLOTO, S.; BAGNATO, V. S. Experimental determination of threshold dose in photodynamic therapy in normal rat liver. Laser Physics Letters, v. 4, n. 6, p. 469-475, 2007.

8 FERRAZ, R. C.; FERREIRA, J.; MENEZES, P. F.; SIBATA, C. H.; SILVA O.C.; BAGNATO, V. S. Determination of threshold dose of photodynamic therapy to measure superficial necrosis. Photomedicine and Laser Surgery, v. 27, n. 1, p. 93-99, 2009. 
9 GIBSON, S. L.; NGUYEN, M. L.; FOSTER, T. H. WHITE, G.; HILF, R. Efficacy of Photodynamic Therapy on Original and Recurrent Rat Mammary-Tumors. Photochemistry and Photobiology, v. 61, n. 2, p. 196-199, 1995.

10 WILSON, B. Physics and biophysics of photodynamic therapy. Medical Physics, v. 32, n. 7, p. 2407, 2005.

11 PATTERSON, M. S.; WILSON, B. C.; GRAFF, R. In vivo Tests of the Concept of Photodynamic Threshold Dose in Normal Rat-Liver Photosensitized by Aluminum Chlorosulfonated Phthalocyanine. Photochemistry and Photobiology, v. 51, n. 3, p. 343-349, 1990.

12 CORTI, L.; SKARLATOS, J.; BOSO, C.; CARDIN, F.; Kosma, L.; KOUKOURAKIS, M. I.; GIATROMANOLAKI, A.; NORBERTO, L.; SHAFFER, M.; BEROUKAS, K. Outcome of patients receiving photodynamic therapy for early esophageal cancer. International Journal of Radiation Oncology Biology Physics, v. 47, n. 2, p. 419-424, 2000.

13 MAIER, A.; TOMASELlI, F.; GEBHARD, F.; REHAK, P.; SMOLLE, J.; SMOLLEJUTTNER, F. M. Palliation of advanced esophageal carcinoma by photodynamic therapy and irradiation. Annals of Thoracic Surgery, v. 69, n. 4, p. 1006-1009, 2000.

14 SHIMADA, Y.; MAEDA, M.; WATANABE, G.; YAMASAKI, S.; KOMOTO, I.; KAGANOI, J.; KAN, T.; HASHIMOTO, Y.; IMOTO, I.; IZAWA, J.; IMAMURA, M. Cell culture in esophageal squamous cell carcinoma and the association with molecular markers. Clinical Cancer Research, v. 9, n. 1, p. 243-249, 2003.

15 CALZAVARA, F.; TOMIO, L.; CORTI, L.; ZORAT, P. L.; BARONE, I.; PERACCHIA, A.; NORBERTO, L.; DARCAIS, R. F.; BERTI, F. Esophageal Cancer Treated by Photodynamic Therapy Alone or Followed by Radiation-Therapy. Journal of Photochemistry and Photobiology B-biology, v. 6, n. 1-2, p. 167-174, 1990.

16 SCHAFFER, M. CORTI, L. HOLLENHORST H. BOSO, C.; SCHAFFER, P. M.; BUSCH, M.; DUHMKE, E. Combined treatment modality of esophageal cancer: Radiation therapy (RT) with photodynamic therapy (PDT). European Journal of Cancer, v. 33, p. 67, 1997.

17 SINGH, G.; ESPIRITU, M.; SHEN X. Y.; HANLON, J. G.; RAINBOW, A. J. In vitro induction of PDT resistance in HT29, HT1376 and SK-N-MC cells by various photosensitizers. Photochemistry and Photobiology, v. 73, n. 6, p. 651-656, 2001. 
18 CASAS, A.; SANZ-RODRIGUEZ, F.; DI VENOSA, G.; PEROTTI, C.; MAMOME, L.; RODRIGUEZ, L.; SIMIAN, M.; JUARRANZ, A.; PONTIGGIA, O.; HASAN, T.; BATLLE, A. Disorganization of cytoskeleton in cells resistant to photodynamic treatment with decreased metastatic phenotype. Cancer Letters, v. 270, n. 1, p. 56 (2008).

19 INCA - Instituto Nacional do Câncer. Disponível em: http://www1.inca.gov.br/estimativa/2010/. Acesso em: 12 de dezembro de 2009.

20 WEINBERG, R.A. The biology of cancer, New York: Garland Science, 2007.

21 E-CANCER - Informações para uma vida melhor. Disponível em: http://andre.sasse.com/futuro.htm. Acesso em: 14/12/2009.

22 BAGNATO, V.S.; KURACHI, C.; FERREIRA, J.; MARCASSA, L.G.; SIBATA, C.H.; ALLISON, R.R. PDT experience in Brazil: A regional profile. Photodiagnosis and Photodynamic Therapy, v. 2, n. 2, p. 107-118, 2005.

23 GROSSWEINER, L. I. PDT light dosimetry revisited. Journal of Photochemistry and Photobiology B-biology, v. 38, n. 2-3, 258-268, 1997.

24 CALZAVARA-PINTON, P. G.; VENTURINI, M.; SALA, R. J. Photodynamic therapy: update 2006. Part 1: Photochemistry and photobiology. European Academy of Dermatology and Venereology, v. 21, n. 3, p. 293-302, 2007.

25 BRANCALEON, L.; MOSELEY, H. Laser and non-laser light sources for photodynamic therapy. Lasers in Medical Science, v. 17, n. 3, p. 173-186, 2002.

26 COLUSSI, V. C. Intensificação da terapia fotodinâmica do câncer pela variação da pressão parcial do oxigênio no tecido: efeitos físicos e biológicos. 1997. 100 f. Tese (Doutorado em Neurociências), Faculdade de Ciências Médicas, UNICAMP, Campinas, 1997.

27 KUSHIBIKI, T.; SAKAI, M.; AWAZU, K. Differential effects of photodynamic therapy on morphologically distinct tumor cells derived from a single precursor cell. Cancer Letters, v. 268, n. 2, p. 244-251, 2008. 
28 NOWELL, P.C. The clonal evolution of tumor cell populations. Science, v. 194, p. 23-28, 1976.

29 BUTKOV, E. Mathematical Physics. New York: Addison-Wesley Publishing Company, 1968.

30 WHEELER, J. A.; ZAGARS, G. K.; Ayala, A. G. Dedifferentiation of locally recurrent prostate cancer after radiation therapy. Evidence for tumor progression. Cancer, v. 71, n. 11, p. 3783-7, 1993. 